\title{
Instituciones suicidas*
}

\author{
ERNESTO GARZÓN VALDÉS \\ Universidad de Maguncia
}

El presente trabajo se centra en el análisis de dos instituciones que fueran concebidas como las más eficaces para la defensa de la autonomía individual: la democracia representativa y el mercado. Ambas aspiran a garantizar el máximo posible de libertad dentro de un marco normativo. Pero ambas, libradas a sí mismas, tienen también la propiedad disposicional de autodestruirse. Pueden, pues, ser llamadas «instituciones suicidas». El medio más eficaz para impedir que ello suceda es establecer límites éti- cos al funcionamiento de la democracia representativa y del mercado. Tras someter a crítica diferentes propuestas formuladas al respecto -estrechamente vinculadas con el problema de la legitimidad de los sistemas políticos y la fundamentación racional de las normas morales - se esboza una vía de solución que parte de la aceptación de restricciones a las posibilidades de decisión parlamentaria («coto vedadon) y de la formulación de lo que podría llamarse ecircunstancias del mercado».

\section{Introducción}

En el ciclo de conferencias que hoy inicio y al que he dado el título algo patético «Instituciones suicidas", deseo ocuparme de una cuestión que me parece relevante para el análisis de las relaciones entre ética y política. El objetivo final es poner de manifiesto hasta qué punto la ética es indispensable para el control de instituciones que, libradas a sí mismas, tienden a autodestruirse, si no formalmente, sí substancialmente. Lo grave no es el simple hecho del "suicidion sino las consecuencias del mismo dado el tipo de instituciones a las que quiero referirme: la democracia y el mercado. Ambas aspiran a conferir vigencia y a proteger la autonomía de la persona dentro de un marco lo más amplio posible de igualdad.

A fin de facilitar la comprensión de mi exposición y de cumplir con un deber de cortesía intelectual, quiero explicitar brevemente la perspectiva desde la que habre de considerar el problema de las einstituciones suicidas».

Mi punto de partida es que la ética se ocupa de la justificación última de las normas que rigen (o deberían regir) las relaciones entre seres huma-

* Este es el texto de las Segundas Conferencias Aranguren de Filosofia que, organizadas por el Instituto de Filosofía, fueron impartidas pör el profesor Emesto Garzón Valdés en la Residencia de Estudiantes los dias 8.15 .22 y 29 de marzo de 1993. 
nos. Características éticas fundamentales de los seres humanos son el poseer autonomía (o libertad individual) y el ser recíprocamente iguales con respecto a esta autonomía.

Conferir importancia central a la autonomía de la persona -entendida en el sentido kantiano de la palabra- significa, por una parte, adoptar una posición que en el campo de la filosofía política ha encontrado su formulación más acabada en el liberalismo democrático. Por otra, desde el punto de vista ético, implica, primero, el rechazo de aquellas posturas que, bajo el nombre genérico de "comunitarismo», postulan la reducción o la subordinación de la identidad personal a la comunidad étnica o cultural. Segundo, la no aceptación de concepciones consecuencialistas, que pueden ser incluidas bajo la designación genérica de utilitarismo, una de cuyas manifestaciones en la filosofía política es el neoliberalismo.

Como es sabido, buena parte de la discusión ético-política contemporánea se centra en la viabilidad de la concepción liberal del Estado tras los fuertes ataques lanzados por los comunitaristas al liberalismo político y a la concepción kantiana de la autonomía individual. Conviene recordar algunos argumentos comunitaristas. Según Chandran Kukathas: ${ }^{1}$

El liberalismo, con su testanuda insistencia en concebir a la sociedad en términos individualistas, [...] es incapaz de dar cuenta del fenómeno de la lealtad grupal y de la reafirmación cultural.

o, en la formulación radical de John Gray: ${ }^{2}$

En el contexto intelectual y político de la última década de nuestro siglo, no es posible seguir manteniendo - ni siquiera como ficciones útiles- los mitos de la modernidad liberal: los mitos del progreso global, de los derechos fundamentales y de un movimiento secular hacia una civilización universal.

A nivel ético-filosófico, la ofensiva en contra de una supuesta prescindencia de los datos empírico-comunitarios apunta principalmente al concepto de autonomía tal como fuera formulado por Kant y reactualizado, sobre todo, por John Rawls en Una teoría de la justicia. Las diversas corrientes del posmodernismo y del comunitarismo pueden ser entendidas como una confrontación con el concepto de autonomía kantiano al que se le reprocha, sobre todo, su carácter abstracto, ajeno a los condicionamientos de la realidad. No tiene sentido, se aduce, hablar de la autonomía de seres noumenales, indiscernibles por carecer justamente de identidad individual, empírica, como los que Kant propone como sujetos morales. ${ }^{3} \mathrm{Si}$ se quiere dar cuenta del problema concreto de la autonomía personal de seres reales, no idénticos, habría que poner el acento en el marco social en el que se desenvuelve la vida de cada individuo.

Esta actitud antikantiana explica la revalorización, principalmente en 
el mundo anglosajón, del pensamiento hegeliano iniciada por Charles Taylor con su insistencia en que la plena realización de la libertad individual presupone una sociedad cuyos valores y prácticas constituyen whorizontes dotados de autoridad" que "fijan nuestros fines": sólo como miembros de una sociedad podriamos lograr nuestra existencia moral completa, ${ }^{5} \mathrm{O}$, en una formulación más reciente:

Deseo defender la tesis fuerte según la cual actuar sin marcos de referencia es algo totalmente imposible para nosotros [...] La tesis es que vivir dentro de estos horizontes fuertemente cualificados es constitutivo del carácter de actor humano," que salir fuera de estos límites equivale a salir de lo que reconoceríamos como personalidad humana integral, es decir, no dañada.

Saber quién soy es una forma de conocer dónde estoy. Mi identidad es definida por las obligaciones e identificaciones que proporciona el marco u horizonte dentro del cual puedo tratar de determinar, de caso en caso, qué es bueno, o valioso, o qué debe hacerse o qué debo aprobar o rechazar.

[Cuando la gente dice que pertenece a una determinada religión o nación], lo que está diciendo no es que se siente fuertemente unida a esta visión o trasfondo espiritual; más bien es éste el que proporciona el marco dentro del cual puede precisar dónde está situada en cuestiones acerca de lo que es bueno, apreciable, admirable o valioso.

[...]

Esto pone de manifiesto que hay un nexo esencial entre identidad y una especie de orientación. Saber quién se es es estar orientado en un espacio moral [...]. ${ }^{6}$

La objeción de Taylor en contra de los liberales de cuño kantiano es que ellos creen que es posible separar el sí mismo de los fines, o que aquél tiene prioridad sobre estos últimos. No muy diferente es la posición de Michael Sandel cuando argumenta que el sí mismo no es anterior a, sino que está constituido por, los fines. Y estos fines no los elegimos sino que los descubrimos por estar inmersos en algún contexto social compartido:

"Decir que los miembros de una sociedad están ligados por un sentido de comunidad no es simplemente decir que un gran número de ellos profesan sentimientos comunitarios y persiguen fines comunitarios, sino más bien que ellos conciben su identidad [...] como definida en cierta medida por la comunidad de la cual son parte. Para ellos, la comunidad describe no sólo lo que ellos tienen como conciudadanos sino también lo que son, no una relación que ellos eligen [...] sino un lazo que ellos descubren, no meramente un atributo sino un constituyente de su

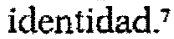

Alasdair MacIntyre es otro de los representantes de la reacción contra Kant dentro de la corriente del comunitarismo. Según él, la persona es, en sus acciones y en su práctica, "un animal narrador de historias»: "puedo dar respuesta a la pregunta '¿qué tengo que hacer?' sólo si puedo dar res- 
puesta a la pregunta previa '¿de qué historia o historias encuentro que formo parte? $?_{n: 8}^{8}$

Heredo del pasado de mi familia, de mi ciudad, de mi tribu, de mi nación, una variedad de deudas, legados, expectativas y obligaciones legitimas. Ello constituye lo dado de mi vida, mi punto de partida moral. Esto es, en parte, lo que confiere a mi vida su propia particularidad moral.

Este pensamiento probablemente parecerá extraño y hasta sorprendente desde el punto de vista del moderno individualismo. Desde el punto de vista del individualismo, yo soy lo que yo mismo elijo ser. [...] el joven alemán que cree que haber nacido después de 1945 significa que lo que los nazis hicieron a los judíos no tiene relevancia moral para su relación con los judíos contemporáneos, exhibe la misma actitud de acuerdo con la cual el sí mismo es separable de sus roles y status historicos. [...] El contraste con la visión narrativa del si mismo es claro. Pues la historia de mi vida está siempre inmersa en la historia de esas comunidades de las que derivo mi identidad. He nacido con un pasado; y tratar de separarme de ese pasado a la manera individualista es deformar mis relaciones actuales. La posesión de una identidad histórica y la posesión de una identidad social coinciden. ${ }^{9}$

La posición comunitarista resulta difícil de aceptar, sobre todo por lo que respecta al carácter vinculante del marco de referencia social, que confiere una prioridad ética a la comunidad sobre el individuo, ya que es ella la que define la identidad individual (Sandel) o fija whorizontes dotados de autoridad» (Taylor) y sólo puedo saber qué debo hacer si conozco de qué historia formo parte (MacIntyre). Llevada hasta sus últimas consecuencias, esto significaría tener que adoptar siempre una actitud de resignado conservadurismo frente a los marcos comunitarios en los que nos ha tocado nacer, cosa que no parece estar dispuesto a admitir MacIntyre cuando dice que uno no tiene por qué respetar las "limitaciones morales" de la comunidad. ${ }^{10}$

Pero, justamente la posición liberal kantiana insiste en la posibilidad de someter a examen crítico las pautas impuestas por la comunidad en la que uno actúa, sin que ello signifique la pérdida del sí mismo. A tal fin, ofrece como pauta un concepto normativo de la autonomía personal que está libre de precisiones empíricas a fin de que su voluntad legisladora pueda tener vigencia universal. ${ }^{11}$

Es esta vigencia universal de la ley moral la que también pone en duda la posición comunitarista. Es obvio que quien concede prioridad moral a la comunidad tiene que sostener, por razones de coherencia, la relatividad espacial y temporal de los juicios morales y aceptar la Sittlichkeit hegeliana como instancia última de aquéllos. Michael Walzer puede, por ello, afirmar:

Todos nosotros somos creaturas productoras de cultura; hacemos y habitamos mundos dotados de sentido. Pero, como no hay forma de establecer una jerarquía 
entre estos mundos y de ordenarlos con respecto a su comprensión de los bienes sociales, hacemos justicia a las mujeres y hombres reales si respetamos sus creaciones particulares. [...] La justicia está enraizada en distintas comprensiones de lugares, honores, trabajos, cosas de todo tipo, que constituyen una forma compartida de vida. Arrasar estas comprensiones es (siempre) actuar injustamente. ${ }^{12}$

Si esto es así, no se entiende qué fundamento moral puede aducir un individuo que, siguiendo la posibilidad contemplada por MacIntyre, pretenda superar las "limitaciones morales» de su propia comunidad. Sobre todo, resulta difícil aceptar desde el punto de vista ético la imposibilidad de establecer jerarquías entre formas de vida por lo que respecta a su calidad moral. ${ }^{13} \mathrm{Me}$ cuesta entender que quien esté dispuesto a "arrasar» comprensiones comunitarias, según las cuales, por ejemplo, el color de la piel es el dato primario para la distribución de bienes y cargas en una sociedad, actúa por ello «injustamente».

Una versión más débil de la importancia del marco comunitario para la identidad personal es la de Will Kymlicka, quien considera que la comunidad es un kcontexto de elección" que puede perfectamente ser calificado de «bien primario» tal como entienden esta expresión autores liberales como John Rawls o Ronald Dworkin. ${ }^{14}$

Según Kymlicka, aceptar que las diferentes culturas son los acontextos de elección» de nuestras decisiones en la vida práctica es importante, ya que así se pone de manifiesto hasta qué punto «el espectro de opciones está determinado por nuestra herencia cultural». ${ }^{15}$ Por ello,

[...] los liberales deberian interesarse por el destino de las estructuras culturales, no porque ellas tengan algún status moral por sí mismas, sino porque sólo teniendo una estructura cultural rica y segura la gente puede tener conciencia en una forma vivida de las opciones de que dispone y examinar inteligentemente su valor.

[...]

La membrecía cultural sigue siendo un bien primario, cuya consideración es una parte importante de la preocupación igual por los individuos. ${ }^{16}$

Pero, el valor ético de un "contexto de elección", al igual que el de una forma de vida de una determinada comunidad, depende de la medida en que este contexto tome en cuenta el respeto a la autonomía de la persona, entendida en el sentido normativo kantiano, a partir de la cual puede cada cual desarrollar una identidad moralmente valiosa y, en este sentido, digna de respeto y no «arrasable». Si los contextos de elección fueran bienes primarios, como sostiene Kymlicka, merecerían, ya por el simple hecho de serlo, el mismo respeto que el bien primario de la libertad individual, algo que resulta difícil de aceptar cuando aquél contradice esta última e impone, por ejemplo, la esclavitud. 
En lo que sigue no sólo habré de suponer el valor primario de la autonomía de la persona como ser individual, sino que también habré de postular que, para ingresar en el discurso ético, es necesario aceptar el marco fijado por la perspectiva de la imparcialidad y por la exigencia de universabilidad de las normas éticas. Sobre este punto habré de volver en la última de las conferencias.

Y ahora, veamos más de cerca la primera de las instituciones "suicidas»: la democracia.

\section{El caso de la democracia}

Pienso que no es muy aventurado afirmar - utilizando una formulación de Robert Nozick - que el problema central de la filosofía política es dar respuesta a la cuestión de cómo es posible justificar racionalmente la existencia del Estado, si es que se acepta que toda persona, justamente en virtud de su autonomía, tiene que experimentar como una verdadera lesión la imposición de coacciones heterónomas.

En las versiones clásicas de la justificación racional del Estado, como las de Thomas Hobbes y John Locke, al igual que en versiones contemporáneas, como las de James M. Buchanan y Robert Nozick, el deseo de obtener un mínimo de seguridad -entendida como la liberación del temor a ser lesionado en la propia integridad física o en la propiedad-es necesario y hasta suficiente para explicar el surgimiento del orden estatal, es decir, la implantación de un sistema jurídico dotado de poder sancionador y capaz de imponer heterónomamente formas de comportamiento. El argumento parte de la suposición de que todo ser racional, es decir, que esté en condiciones de apreciar sus propios intereses, habrá de aceptar que sólo la existencia de un orden coactivo puede garantizar una convivencia en la que el "bien» de la paz social supera ampliamente los "males» que pueda requerir su mantenimiento.

Sin embargo, entre la argumentación de Hobbes-Buchanan y la de Locke-Nozick existe una diferencia esencial: según la primera, la seguridad no sólo es condición necesaria y suficiente para la explicación del surgimiento del Estado sino, también, para su justificación; según la segunda, es tan sólo una condición necesaria para su justificación, ya que para obtener una justificación plena habría que recurrir a condiciones adicionales tales como la existencia del consentimiento que presten los miembros de una sociedad estatal a las medidas gubernamentales que puedan afectar su propiedad. Por ello, la llamada «cláusula cautelar de Locke» y las urestricciones laterales" de Nozick permiten justificar la desobediencia civil dentro del sistema y hasta su derrocamiento revolucionario.

Dicho con otras palabras: en el primer caso, de lo que se trata es más bien de una explicación del surgimiento del Estado que funciona también 
como razón justificante. En el segundo, se introduce una distinción relevante entre explicación y justificación. En el primer caso, la atención se centra en la mera existencia del Estado; en el segundo, en su existencia éticamente aceptable.

En la versión Hobbes-Buchanan, los miembros de la sociedad resuelven recurrir a la fundación de un orden coactivo estatal por razones prudenciales (prefieren la restricción coactiva de formas de comportamiento al peligro de ser dañados arbitrariamente por sus congéneres). Procuran, así, maximizar la promoción de sus intereses.

Pero ya Hobbes sabía también que la línea de la maximización de los propios intereses tenía sus límites por lo que respecta a su aporte de justificación y tropezaba con la imposibilidad de dar una respuesta exhaustiva a la cuestión de saber por qué quien aspira a la persecución coherente de sus propios intereses no ha de aspirar también a asegurarse la doble ventaja del cumplimiento del contrato por parte de los demás y del no cumplimiento por su parte. La calificación de este comportamiento como parasitario es sólo posible si se trasciende el nivel de los propios intereses y se aceptan otros valores adicionales tales como la equidad o la imparcialidad. Hobbes no estaba, desde luego, dispuesto a dar este paso y prefirió estigmatizar la cuestión como la pregunta del "tonto", que no merecía respuesta.

El intento más reciente $-\mathrm{e}$ infructuoso- de ofrecer una respuesta a la pregunta del tonto partiendo de la perspectiva de la promoción racional de los propios intereses es el de David Gauthier. Sin embargo, tampoco en su propuesta de solución se comprende por qué los individuos han de renunciar, en la persecución de sus intereses, al recurso del engaño y del fraude e ignorar sus ventajas estratégicas. ${ }^{17}$

El fracaso de Gauthier es un ejemplo modélico de la insuficiencia del recurso a razones puramente estratégicas para lograr una fundamentación moral de la organización estatal. Para decirlo con una fórmula de Georg H. von Wright: 18

La posibilidad de agregar a los beneficios del reino de la justicia las ventajas de una acción injusta, dicho brevemente: la posibilidad de lo que hemos llamado acción parasitaria, pone de manifiesto un sentido importante en el que puede decirse que la justicia y la moralidad carecen esencialmente de justificación utilitarista.

Si se acepta la posición ética que aquí he propuesto, no cuesta mucho admitir también que la justificación éticamente aceptable de una forma política es aquella que procura conciliar la autonomía personal con la convivencia de seres iguales. La tarea de la ética política consistiría en justificar, desde una perspectiva de imparcialidad y con normas universalizables, todo apartamiento de la libertad y la igualdad. Dicho con otras palabras, de lo que se trata es de la conciliación entre libertad e igualdad, que 
es justamente la que subyace a la idea de la democracia. A través de ella, la libertad natural se convierte en libertad política.

Pero la libertad política en sentido fuerte es sólo posible en un orden en el que cada cual obedece únicamente aquellas normas que él mismo estaría dispuesto a darse. En este sentido, sólo las normas unánimemente aceptadas estarían éticamente justificadas. Posiblemente ni la llamada concepción clásica de la libertad dentro de un orden estatal, que fuera contrapuesta a la idea de la libertad "germánica" sin Estado, satisfacía este requisito de la garantía de la libertad en sentido fuerte. La libertad de la democracia fue sometida a una restricción adicional al aceptarse como legítimas las decisiones de la mayoría y éstas fueron reemplazadas, en virtud de la impracticabilidad de la democracia directa en sociedades numerosas, por las decisiones de la mayoría parlamentaria.

El parlamentarismo constituye un compromiso entre la exigencia democrática de libertad y la división del trabajo impuesta por las modernas sociedades nacionales. ${ }^{19}$ Justamente también debido a la complejidad de las sociedades contemporáneas, el "pueblo» en cuanto tal no está en condiciones de practicar la democracia directa y, por ello, debe limitarse a la creación del organo que forme la voluntad estatal. Pero, por otra parte, como se desea conservar la apariencia de que en el parlamento se expresa inquebrantablemente la idea de la libertad, se recurre a la ficción de la representación, a la idea de que el parlamento es tan sólo un representante del pueblo y que en el parlamento el pueblo expresa su voluntad, a pesar de que en todas las constituciones liberales se acepta el principio del mandato libre del representante, es decir, su no sujeción a instrucciones por parte de los representados. Esta independencia del representante con respecto a los representados es lo que distingue al parlamento moderno de las antiguas representaciones estamentales en donde existía el sistema del mandato imperativo.

En frase de José Luis Aranguren:20

La representación es un sucedáneo de la, en su plenitud, imposible democracia [directa]. Y así puede funcionar como una ficcion, por necesaria, plausible, siempre que se cumplan dos condiciones: que se mantenga la vinculación estrecha y constante de los representantes con sus representados, para que el sistema representativo no degenere en parlamentarismo o en partitocracia [...] y que tampoco el gesto ritual de votar [...] se convierta en un acto aislado de la secuencia de una concepción democrática de la vida [...].

La repręsentación es, pues, una ficción que pretende legitimar el parlamentarismo desde el punto de vista de la soberanía popular. Las decisiones tomadas por el parlamento (o por el "rey en el parlamenton, para usar la formula inglesa) fueron consideradas como expresión de la soberanía del pueblo. 
Esta idea de la soberanía parlamentaria es la que estaba presente en sus primeros teóricos. Tal es el caso, por ejemplo, de Ednuund Burke, el gran apologeta del mandato libre, cuando en su famoso discurso a los electores de Bristol, decía:

El parlamento no es un congreso de embajadorcs con intereses hostiles y diferentes, que cada uno debe sustentar como un agente y un abogado frente a otros agentes y abogados, sino que el parlamento es la asamblea deliberadora de una nación con un interés, el de la totalidad, donde los prejuicios locales no deberían servir de guía, sino el bien general resultante de la razón general de la totalidad. ${ }^{21}$

Pero, una vez consumado el triunfo de la idea del parlamentarismo con mandato libre, lo que se puso en tela de juicio fue justamente la viabilidad de esta ficción. Se argumentó entonces que la voluntad que se forma en el parlamento no es la voluntad del pueblo. Las críticas más severas y eficaces en contra del parlamentarismo, por ejemplo, las de Carl Schmitt y las más recientes en contra de la omnipotencia del parlamento, como las de Karl Popper o de H. Steinberger, 22 no se dirigen en contra del procedimiento parlamentario en sí mismo sino en contra de su insuficiencia para cumplir con el fin para el que fue creado, es decir, el aseguramiento de la autonomía individual. No es una crítica meramente formal sino substancial. Esta crítica está basada justamente en la idea de la soberanía del parlamento. Si el parlamento es soberano y deben aceptarse sus decisiones tomadas por mayoría, toda restricción a sus poderes es lógicamente imposible. Esto es lo que ha sido llamado la "paradoja de la democracia" o la "paradoja de la libertad". Según Popper, la aceptación de la omnipotencia del parlamento

Ha puesto en una posición intelectualmente desesperada a todos los democratas que adoptan como la base últíma de su credo político el principio de la regla de la mayoría o una forma similar del principio de la soberanía. Por una parte, el principio que ellos adoptan les exige que se opongan a toda regla como no sea la de la mayoría y, por lo tanto, a una tiranfa; por otra, el mismo principio les exige aceptar toda decisión adoptada por mayoria y, asi, la regla del nuevo tirano [que la mayoria pueda haber decidido establecer, E.G.V.].3

Dos son los argumentos que deseo utilizar para poner de manifiesto el peligro de la tendencia suicida del parlamento. El primero se refiere a la ilimitabilidad de la soberanía; es un argumento de naturaleza lógica que apunta a la inconsistencia de toda versión de la teoría de la soberanía que acepte la existencia de limitaciones jurídicas al poder del soberano. El segundo hace referencia a la tendencia humana a comportamientos parasitarios o, lo que es lo mismo, la tendencia al aumento egoísta del poder; éste es un argumento de naturaleza más bien psicológica. A ambos quiero ahora referirme. 


\subsection{Democracia y soberania}

En la filosofía jurídica, John Austin es posiblemente uno de los autores que con más claridad ha expuesto los problemas lógicos de una autolimitación jurídica del soberano. Quiero mencionar aquí tan sólo dos de sus argumentos:

a) La autolimitación del soberano es una contradictio in terminis.

b) Es imposible lógicamente darse normas a uno mismo.

a) El primer argumento deriva de la definición que Austin propone de soberano. De acuerdo con su concepción, el soberano está caracterizado por una nota positiva y otra negativa. La primera significa que el soberano es la persona o grupo de personas cuyas óndenes son obedecidas habitualmente por la mayoría de la población. La segunda significa que esta persona o grupo de personas no obedece habitualmente a ninguna otra persona o grupo de personas. ${ }^{24}$

Precisamente porque el soberano, por definicion, es obedecido y es la autoridad jurídica suprema, una limitación jurídica autoimpuesta debería rezar de la siguiente manera:

I) Cada vez que ordene que $P$ no se me debe obedecer.

Esta formulación es contradictoria si se tiene en cuenta que el soberano no sólo es habitualmente obedecido sino que, además, exige obediencia y que el concepto de orden está lógicamente vinculado con el de deber. Pero, sigamos con el ejemplo y supongamos ahora que el soberano anuncia:

\section{II) Ordeno que $P$.}

Evidentemente II) contradice I) y como el soberano es habitualmente obedecido, lo será también en II); más aún, deberá ser obedecido en virtud de la vinculación conceptual que, según Austin, existe entre orden y deber. Es decir que I) es una orden de obediencia imposible (ya que quedaría automáticamente revocada por il) o sea que tampoco es ley alguna.

Tal como lo ha expuesto Thomas Cornides, ${ }^{25}$ la irrevocabilidad de una orden puede ser establecida por la persona que ordena o por un tercero. Aquí nos interesa tan sólo el primer caso. Cornides presenta el ejemplo de Ulises, quien ordena a sus marineros que se tapen los oídos, lo aten a un mástil de su barco y no lo desaten bajo ninguna circunstancia mientras no se alejen de la Isla de las Sirenas. Cuando Ulises dice "¿Desatadme!», ¿qué deben hacer sus marineros? ¿Ha revocado su orden y, por lo tanto, debe ser desatado, o era la primera orden irrevocable y, por lo tanto, debe seguir atado?

Ambas interpretaciones son posibles. Desde luego, si no es desatado (y suponiendo que los marineros tienen el deber de obedecer las órdenes de Ulises y siempre le obedecen), ello significaria que los marineros no han 
tomado su frase en serio, o sea, no la han interpretado como una orden. Si es desatado, la primera orden habría quedado revocada. Y ello pasaría siempre con cualquier orden de ese tipo, es decir, que es una orden de cumplimiento imposible.

b) El argumento de la imposibilidad de dictarse a sí mismo una ley positiva había sido considerado ya por Jean Bodin cuando decia:

Se puede perfectamente estar bajo la ley de algún otro, pero reside en la naturaleza de las cosas que nadie puede darse a sí mismo algo que exclusivamente dependa de su voluntad [...] Y así como [...] el Papa no puede atarse las manos, así tampoco puede hacerlo el principe soberano, aun cuando lo quisiera. ${ }^{26}$

Vistas así las cosas, la paradoja de la soberanía o de la libertad resulta insuperable. En ella se apoyó Platón para criticar la democracia; el tránsito legislativo de la democracia de Weimar al régimen nazi con la ley de plenos poderes otorgados a Hitler es una buena prueba no muy lejana de la posibilidad fáctica del suicidio democrático. ${ }^{27}$

\subsection{Democracia y comportamiento parasitario}

Veamos ahora el segundo factor del "suicidio": la tendencia al comportamiento parasitario o al aumento egoísta del poder. Una buena concepción de un actor racional es aquella que sostiene que todo ser racional aspira a maximizar sus beneficios y reducir sus costos. Todo enfoque económico de las relaciones de poder tiene que centrarse justamente en este cálculo de utilidades. Si se parte de la definición de poder generalmente aceptada según la cual decir que $A$ tiene poder sobre $B$ equivale a decir que $A$ logra que $B$ haga algo que no hubiera hecho si A no se lo hubiese ordenado y de la idea de que una de las formas más eficaces de aumentar los propios beneficios y reducir los costos es procurar que los demás hagan lo que uno quiere, no cuesta mucho inferir que quien detenta el poder ha de procurar aumentarlo mediante la imposición heterónoma de comportamientos que lo beneficien, es decir, lesionando la autonomia de los demás. El tonto de Hobbes no era tal; por el contrario, seguía fielmente las prescripciones de la elección racional: maximizar los beneficios y reducir los costos. Cuanto más racional sea el agente, tanto más tenderá a comportamientos parasitarios y, desde luego, a conservar y aumentar su posición de poder.

Este aumento de poder (o de control heterónomo) no tiene por qué violar las reglas del procedimiento democrático. El moderno Leviatán descrito por James M. Buchanan, ${ }^{28}$ concretamente el sistema político norteamericano, no habría sido el resultado de la violación del procedimiento democrático. Así, al referirse a la crisis de los años 1960 y 1970, afirma: 
Lo que hay que subrayar es que este crecimiento ha ocurrido, casi exclusivamente, dentro del funcionamiento predecible de correctos procedimientos democráticos,

Los autores de la Constitución de los Estados Unidos [...] no previeron la necesidad de controlar el crecimiento del autogobiemo [...] Los límites o restricciones de las agencias gubernamentales [...] fueron discutidos primariamente en términos del mantenimiento de procedimientos democráticos. Los gobernantes fueron sometidos a las leyes a causa de una previsible proclividad a extender sus propios poderes más alla del límite procedimental, a expensas presumiblemente de la ciudadanía. Pero, implícitamente, en buena parte de la discusión estaba la noción de que, en la medida en que el procedimiento democrático funcionase, no habia necesidad de establecer límites. ${ }^{z}$

La tendencia al aumento del poder es lo que Buchanan llama el «apetito de las coaliciones mayoritarias» $(1975,151)$ que, al igual que en el caso de las personas, suele conducir a la obesidad, sin que en ningún momento se hayan violado las reglas de la elección racional:

No tiene que estar presente una manifiesta glotonería ni tampoco ningún error. En el momento de cada elección especifica de consumo de alimentos, los beneficios esperados excedian los costos esperados. ${ }^{30}$

Llamaré a este peligro el "peligro de la obesidad mayoritaria».

Otra manifestación de esta misma tendencia a la autodestrucción de la democracia parlamentaria es aquello que Macaulay llamaba el “despotismo elegido»:31

La tendencia de la democracia representativa a convertirse en el «despotismo elegido" del partido gubernamental; los políticos, lejos de ser una defensa primaria en contra de la maquinaria gubernamental, explotan al máximo sus potencialidades de la administración centralizada y jerarquizada a fin de realizar un número limitado de sus propios objetivos.

Una tercera forma del ejercicio del poder de la mayoría parlamentaria con graves consecuencias para la promoción de la autonomía de los electores es el fenómeno de la no decisión, estudiado clásicamente por Bachrach y Baratz. Según ellos, un análisis satisfactorio del poder implica tanto la consideración de la toma de decisiones como de la no toma de decisiones. Una decisión «es una elección entre modos alternativos de acción»; una no decisión es una "decisión que resulta en la supresión o frustración de un desafío latente o manifiesto a los valores o intereses del decisorn. La no toma de decisión es «un medio mediante el cual los pedidos de cambio en la distribución existente de beneficios y privilegios en la comunidad pueden ser sofocados antes de que sean formulados; o mantenidos encubiertos; o sofocados antes de que accedan al foro relevante para la toma de decisiones $[\ldots] » .{ }^{32}$ Dicho brevemente: 
Una persona o grupo posee poder [en este sentido] en la medida en que, consciente o inconscientemente, levanta o refuerza obstáculos en contra de la consideración pública de conllictos. ${ }^{33}$

Schattschneider, en quien se apoyan Bachrach y Baratz, utiliza la siguiente formulación:

Todo tipo de organización política tiene la tendencia a explotar determinados conflictos y a silenciar otros, pues organización significa movilizar prejuicios. Algunos problemas son intencionalmente preferidos en la política y otros intencionalmente excluidos..$^{34}$

Esta cuestión está vinculada con la composición del cuadro de alternativas presentadas a los votantes. La composición de la agenda política influye directamente en la formación de las preferencias de los votantes:

Las preferencias [políticas, E.G.V.] no existen independientemente de las instituciones a través de las cuales se expresan; su formacion es, al menos parcialmente, endógena al proceso de la formación de la agenda que, por consiguiente, tiene que ser vista como un mecanismo más bien deliberativo que puramente agregativo. ${ }^{35}$

Esta formación endógena de las preferencias de los ciudadanos es una forma sutil de ejercicio del poder, que puede ser incluida dentro de la categoría de la manipulación o de la indoctrinación y debe ser tenida en cuenta porque también constituye una lesión de la autonomía de la persona. Este puede ser llamado el peligro de la "agenda impuesta».

Tal vez no esté de más subrayar que en las citas presentadas Buchanan habla de "proclividad"; Macaulay y Schattschneider, de "tendencia". También Bachratz y Baratz, al referirse a la exclusión de temas de la agenda política, comentan:

$¿$ No son estas tendencias necesarias para una investigación del poder? ¿No deberia el investigador estar permanentemente en claro que en las instituciones humanas que investiga pueden estar presentes estas tendencias y que, por lo tanto, siempre tiene que estar dispuesto a investigar las fuerzas que las crean y promueven? ${ }^{36}$

Alguien podría objetar que este discurso de tendencias y proclividades trac consigo una incontrolable psicologización del problema con lo que se abandona toda posibilidad de formular juicios con alguna pretensión de objetividad. Puede ser que haya algo de verdad en esta objeción; pero pienso que no conviene olvidar que en toda descripción de relaciones de poder es inevitable recurrir a conceptos tales como los de preferencia, cálculo de beneficios y costos, así como también a enunciados contrafácticos acerca 
de lo que una persona hubiera hecho si no se hubiese encontrado sometida a una relación de poder. Y si se tiene en cuenta que el concepto de poder es un concepto central de la ciencia y la filosofía de la política, creo que no hay más remedio que aceptar la inclusión de estos elementos psicológicos en la consideración de los fenómenos políticos.

Cabe mencionar un cuarto problema que ha sido expuesto principalmente por los representantes de los llamados «Estudios críticos del derecho». Se trata de lo siguiente: la democracia liberal se vería enfrentada con una dificultad insuperable: "la incapacidad de llegar a una comprension coherente de las relaciones entre reglas y valores en la vida social». ${ }^{37} \mathrm{Se}-$ gún Roberto Unger, no existe ningún procedimiento que pueda satisfacer la exigencia de la moralidad política liberal en el sentido de contar con un procedimiento neutral de legislación. Esto es lo que ha sido llamado la "antinomia de la legislación». Según Unger, ella estaría enraizada en el hecho de que en la teoría liberal los valores son considerados como subjetivos. Esto significa que los valores expresados por la mayoría legislativa constituyen siempre una coerción para quienes no los comparten. Un proceso legislativo neutral es, según Unger, imposible por dos razones:

Primero, el procedimiento es inseparable del resultado: todo método vuelve más probables ciertas elecciones legislativas que otras. [...] Segundo, todo sistema legislativo implica ciertos valores; incorpora una concepción de cómo debe ser distribuido el poder en la sociedad y cómo deberían ser resueltos los conflictos. ${ }^{38}$

La consecuencia que infiere Unger es que en un sistema liberal democrático representativo, la rule of law es a la vez necesaria e imposible. En este sentido, cada acto legislativo contribuiría a la autodestrucción del sistema. La "paradoja de Unger» resulta del piuralismo valorativo de las premisas liberales que vuelve necesaria la existencia de reglas para gobernar la sociedad a la vez que imposibilita un acuerdo acerca del procedimiento para el dictado de esas reglas. Sobre los "Estudios críticos del derecho" volveré en la tercera conferencia.

Una versión más benigna de la "paradoja de Unger» es la que podría ser llamada la "contradicción de Hirst», Según Paul Hirst, existe una contradicción interna en la concepción que sostiene que porque las leyes son reglas generales universalmente aplicables no pueden lesionar derechos individuales. Se supone que el parlamento sanciona leyes generales y que el ejecutivo es una agencia imparcial para la ejecución de esas leyes. Pero,

[...] en realidad, la mayor parte de la legislación consiste en delegar poderes de decisión y acción a las agencias del Ejecutivo, que tienen el poder derivado para hacer que tales reglas sean tan necesarias y administrar una actividad como lo consideren adecuado dentro de algún marco amplio de objetivos. Las leyes no son tanto normas universales que regulan conductas cuanto una sanción legal de medi- 
das administrativas especificas. [...] La legislación y la acción gubernamentales distan mucho de ser universalmente aplicables; a menudo están dirigidas especificamente a grupos definidos para su beneficio o detrimento. ${ }^{39}$

La «contradicción de Hirst» es otro ejemplo de como un parlamento que actúe de acuerdo con el procedimiento de la democracia representativa puede provocar lesiones graves de la autonomía y la igualdad de las personas, es decir, destruir las bases de su justificación o, lo que es lo mismo, llevar al suicidio de la democracia parlamentaria.

La paradoja de la soberanía, los peligros de la "obesidad mayoritaria", del «despotismo elegido» y de la "agenda impuesta», la antinomia de la legislación y la contradicción de Hirst señalan tendencias de autodestrucción de la democracia. Las tendencias de un agente (individual o colectivo) constituyen lo que suele llamarse también "propiedades disposicionales". Podría, pues, decirse que el cuadro aquí presentado es la descripción de una propiedad disposicional de la democracia representativa.

Si esta disposición es real, el problema puede ser planteado recurriendo a una formulación de James M. Buchanan:

¿Puede el hombre moderno, en la sociedad democrática occidental, inventar u obtener control suficiente sobre su propio destino a fin de imponer restricciones a su propio gobierno que impida su transformación en un genuino soberano hobbesiano? $?^{30}$

Los partidarios de Unger responderían posiblemente que la pregunta es ociosa mientras se pretenda hacer valer la rule of law en una sociedad liberal.

Pero, como si todo esto fuera poco, hay que tener en cuenta que el problema adquiere una dimensión nada promisora si se admite que el mercado libre es condición necesaria (aunque no suficiente) de toda democracia liberal. En efecto, este mercado encierra también el peligro de la autodestrucción. A este tema habré de referirme en la segunda de estas conferencias.

\section{El caso del mercado}

Al igual que la teoría de la democracia representativa, las teorías del mercado, a las que ahora quiero referime, pretenden satisfacer la exigencia del respeto a la autonomía de la persona y parten de un enfoque individualista. $Y$, al igual que la democracia representativa, el mercado posee la propiedad disposicional de su autodestrucción o suicidio. En ambos casos - conviene no olvidarlo- se trata de suicidios y no de homicidios institucionales. El haber centrado el tema en el problema del suicidio no significa, claro está, desconocer el peligro del homicidio. Lo que me importa es 
analizar un aspecto institucional interno que, en cierto modo, puede ser considerado como más grave que el de las agresiones externas ya que hace referencia a una imposibilidad «esencial» de satisfacer los fines para los que ambas instituciones fueron diseñadas.

Tal como lo hiciera en el caso de la democracia, habré de recordar primeramente los argumentos que han solido ser presentados para la justificación ética del mercado y luego procuraré exponer razones sobre la tesis de su autodestrucción.

\subsection{Las justificaciones éticas del mercado}

Las justificaciones que suelen darse del mercado pueden dividirse en dos tipos:

1) el de las llamadas justificaciones intuicionistas o deontológicas;

2) el de las llamadas justificaciones pragmáticas o consecuencialistas.

\subsubsection{Las justificaciones deontológicas del mercado}

En el caso de las justificaciones deontológicas, los argumentos se basan en los valores propios del mercado, que valdrían por sí mismos, o que se expresarían justamente en el mercado en tanto éste no es una vía para obtener otros fines, sino el resultado de la práctica correcta de principios fundamentales como son los vinculados con la defensa de la propiedad y la libertad.

Aquí puede pensarse en dos casos:

2.1.1.1. El mercado es bueno en sí mismo: La bondad intrínseca del mercado se debería a que en él encuentra su manifestación más clara el consenso de quienes participan en él. Si no se quiere recurrir a concepciones metafísicas del bien o usurpar el papel de Dios decidiendo autoritativamente qué es lo bueno y lo malo, el acuerdo mutuo tendría que ser el criterio supremo para juzgar acerca de una situación, cualesquiera que puedan ser sus características. El consenso así entendido sería una expresión cabal de la autonomía de seres iguales y la negación de todo tipo de perfeccionismo.

Es ya casi un lugar común recurrir al llamado "teorema básico de la economía de bienestar» para explicitar la razón fundamental que justifica el mecanismo del mercado.

La primera parte de este teorema afirma que todo equilibrio competitivo es Pareto-óptimo. Es lo que suele ser llamado "teorema directo». La segunda parte del teorema afirma que todo lo que es Pareto-óptimo es un equilibrio competitivo (teorema converso)..$^{41}$ El teorema converso señala la posibilidad de que, si se obtiene una correcta distribución inicial de recur- 
sos, se logra el mejor estado de cosas a través del mecanismo del mercado, sin necesidad de recurrir a intervenciones políticas.

La suboptimalidad de la situación del mercado en el estado de naturaleza es lo que justificaría moralmente el establecimiento de instituciones políticas. Pienso que esta línea de argumentación es la sostenida por James M. Buchanan. En efecto, como es sabido, según Buchanan, ya en el estado de naturaleza existen relaciones de mercado. Los individuos que participan en él pueden ser desiguales por lo que respecta a su riqueza y fortaleza pero son iguales en el intercambio mismo, desde el momento en que existe acuerdo acerca de la estructura de los derechos individuales. En la relación de mercado, las personas actúan como seres individuales dentro del marco de igualdad que confiere el propio mecanismo de intercambio de lo "mío» y lo "tuyo». Esta es la situación que Buchanan llama «distribución natural». No sería necesario ir más allá de ella si no existiera, por una parte, el afán humano de maximizar los propios intereses y, por otra, la tendencia a no reconocer los derechos de propiedad, sobre todo cuando el número de los integrantes de un grupo aumenta apreciablemente. Además, las relaciones competitivas entre un gran número de seres cuyo comportamiento está guiado por motivaciones egoístas son incapaces de crear aquellos bienes que requieren la cooperación de todos. Para superar esta situación de suboptimalidad y evitar la disfuncionalidad que resulta del gasto innecesario de recursos destinados a adquirir y conservar bienes, es indispensable llegar a una «internalización contractual de una relación externa que existe en el estado de naturaleza precontractual $\$ .^{42}$ Surge así el Estado político, cuya función primordial es garantizar el libre juego de las reglas del mercado. El aseguramiento de la vigencia de las reglas del mercado sería la base de la justificación del Estado. Dicho con otras palabras: el Estado estaría justificado si da solución a los problemas que surgen cuando el mercado fracasa, sea porque sus reglas no son respetadas, sea porque la competencia es insuficiente para crear bienes públicos.

2.1.1.2. El mercado como resultado de la aplicación de un procedimiento equitativo. El mercado es bueno - se aduce- porque a él se llega como consecuencia del ejercicio del derecho indiscutible que cada cual tiene de disponer de su propiedad. Un buen ejemplo de esta posición es la de Robert Nozick, con su "historical entitlennent theory». ${ }^{43}$ Se trata de una teoría de la legitimidad de la apropiación que rechaza toda restricción de los derechos individuales de propiedad y requiere un orden económico capitalista.

En este caso, el mercado es el resultado del ejercicio de derechos bási$\cos$ de la persona. Esto presupone que existen reglas para la adquisición y transmisión de la propiedad cuyos resultados tienen que ser aceptados, no 
tanto porque ellos sean buenos, sino porque las reglas son correctas. Cuando ellas no han sido respetadas, es posible introducir correcciones. El resultado es el llamado "Estado mínimo», no redistributivo.

\subsubsection{Las justificaciones pragmáticas (consecuencialistas) det mercado}

Común a las justificaciones pragmáticas ${ }^{44}$ es el intento de justificar la calidad moral del mercado partiendo de premisas no morales. El valor del mercado sería instrumental con respecto a la obtención de bienes que se consideran valiosos, es decir, se trataría de un valor derivado, vinculado causalmente con otros que se consideran supremos o independientes.

En este grupo pueden incluirse:

2.1.2.1. La bondad económica del mercado. Los argumentos que sostienen que los mecanismos del mercado constituyen el instrumento más adecuado para la obtención de los bienes que necesitamos para la supervivencia y que nosotros mismos no estamos en condiciones de producir; por lo tanto, tienen enorme importancia para toda moral práctica dada las utilidades que generan. Dicho con otras palabras: el mercado, en tanto medio para asegurar la riqueza social, tiene una relevancia indirecta para la ética: de su bondad económica se infiere su bondad ética. Es el argumento de la eficiencia.

Este argumento podría ser reforzado recurriendo al llamado teorema de R. Coase, formulado en su ya célebre artículo "The Problem of Social Cost", publicado en 1960.45 Según este teorema, en un mercado libre, sin costos de transacciones, se obtiene una asignación óptima de los recursos, independientemente de la asignación originaria de los derechos de propiedad. La distribución de los derechos no crea ninguna diferencia por lo que respecta a la optimalidad del mercado y esta distribución es indiferente para la fomulación de políticas. El teorema de Coase puede ser considerado como la expresión más radical del principio de eficiencia. Un par de consideraciones de Coase pueden bastar para poner de manifiesto su posición:

La cuestión es comúnmente pensada como una en la que A inflige un daño a $B$ y lo que debe decidirse es icómo deberiamos reprimir a A? Pero esto es falso. Nos enfrentamos aquí con un problema de naturaleza reciproca. Evitar el daño a B infligiría un daño a $\mathrm{A}$. La cuestión real que tiene que ser decidida es: ¿debe permitirse a $A$ que dañe a $B$ o debe permitirse a $B$ que dañe a $A$ ? El problcma es evitar el daño mayor. ${ }^{46}$

\section{$Y$}

Si los factores de producción son pensados como derechos, es más fácil entender que el derecho a hacer algo que tiene efectos perjudiciales (como la produccion de humo, ruido, olor, etc.) es también un factor de producción." 
El conocido ejemplo de Coase es el de la fábrica que contamina el ambiente y daña a los habitantes que viven en las cercanías. Supongamos que la fábrica puede evitar esta contaminación instalando filtros a un costo de 90 dólares con lo que evitaría pagar impuestos por daño de 100 dólares. En este caso, a la fábrica le conviene instalar los filtros. Pero, si por otra parte, los habitantes de los alrededores pueden mudarse o cornprar máscaras a un precio de 40 dólares (y en ambos casos la fábrica corre con los costos correspondientes), esto es lo que debe preferirse pues así se obtiene una ganancia de 50 dólares en el valor de la producción.

2.1.2.2. La conciliación entre los intereses particulares y el bien público. En el mercado la acción de la mano invisible permitiría coordinar los objetivos particulares de las personas en beneficio de la comunidad. El fin obtenido no es el directamente perseguido por las personas que intervienen en el mercado, ya que ellas aspiran tan sólo a la satisfacción de sus propios intereses pero, el mercado los coordina de forma tal que, al final, todas obtienen lo que deseaban y promueven adicionalmente un fin que no formaba parte de sus intenciones.

Como lo recuerda Walter Eucken, ${ }^{48}$

[...] las personas actuando espontáneamente - tal como las describe, por ejemplo, A. Smith- harian surgir la división del trabajo, el intercambio, el ahorro, el dinero y la competencia; las fuerzas libres del individuo conducirían a una exacta formación de los precios en la oferta y la demanda. [...] la «mano invisible» regiría en las leyes inmanentes.

En un famoso capítulo de su Teoria de los sentimientos éticos, afirma A. Smith:

Guiadas por una mano invisible, [las personas, E.G.V.] son conducidas a realizar una división de los bienes necesarios para la vida casi igual a la que se hubicra producido si la Tierra hubiese sido dividida entre sus habitantes en partes jguales; y así, sin proponérselo, sin saberlo, promueven el interés de la sociedad y proporcionan los medios para la multiplicación de la especie. ${ }^{49}$

2.1.2.3. Mercado y libertad de elección. El mercado conferiría a las personas la «libertad para elegir». Esta libertad de elección, que se manifiesta en el mercado a través del intercambio de derechos de propiedad, permite a las personas elegir entre diferentes planes de vida y resolver libremente cuál es el más adecuado para la satisfacción de sus intereses sobre la base de sus posibilidades. No se trata de igualar a las personas en el grado de satisfacción del plan de vida elegido, sino de que cada cual sopese por sí misma la satisfacción que está dispuesta a afrontar.

Si en el caso anterior, en el de la mano invisible, el mercado era visto 
desde la perspectiva de lo que suele llamarse función de bienestar social, aquí lo es desde la perspectiva de la función de la elección social. Es decir, que el mejor de los resultados políticos posibles es juzgado sobre la base de las preferencias de los miembros de una comunidad. ${ }^{50}$

Dicho con una frase de Milton Friedman:

Esta es la diferencia básica entre el mercado y una agencia política. Eres libre para elegir. No hay un policía que te saque el dinero de tu bolsillo para pagar algo que no quieres comprar o para hacer algo que no quieres hacer, ${ }^{51}$

La idea de libertad aquí presente es lo que suele llamarse idea de la libertad negativa y que se expresa diciendo que «queremos organizar nuestras propias vidas, hacer nuestras propias elecciones», ${ }^{52}$ sin interferencias de terceros.

Como se sabe, esta idea de la libertad negativa tuvo su concreción histórica en la política económica europea del siglo XIX. Así, Von Hardenberg en su programa para Prusia decía:

Mi sistema se basa en que cada habitante del Estado es totalmente libre, puede utilizar y desarrollar sus energías con total libertad, sin ser obstaculizado por la arbitrariedad de otro; la justicía es administrada estricta e imparcialmente; el mérito le permite ascender, sin ningún impedimento, cualquiera que sea el estamento al que pertenezca. ${ }^{53}$

Esto último es lo que suele llamarse igualdad de oportunidades en una sociedad en la que impera la meritocracia. Se trata de la aspiración liberal de conciliar la libertad con la eficiencia de un sistema político-económico que admite las diferencias que resultan de la desigualdad de los rendimientos individuales.

La conciliación del egoísmo individual y del bienestar general sería, pues, posible si se asegura la realización del Estado de derecho que estaría basada en la imposición de deberes negativos, es cecir, en la defensa de la libertad negativa. Ella sería - como sostiene Tibor R, Machan- la tarea primaria del gobierno:

El gobierno sirve [...] para proteger nuestra libertad negativa. Tiene que respetar también los principios cuya protección sirve. Por esta razón, la política, desde una perspectiva libertaria, es categorialmente distinta de otras empresas humanas tales como el tratar de tener una buena salud, lograr el perfeccionismo moral o la conservación de monumentos históricos..$^{54}$

Sólo la libertad negativa estaría amenazada en nuestra vida en sociedad: 
La enfermedad, el hambre, el vicio, etc., son plagas que nos afectan en cualquier lugar, dentro o fuera de la sociedad.ss

2.1.2.4. Libertad económica y libertad politica. La libertad económica, asegurada por el mercado libre, sería un medio indispensable para lograr la libertad política. Milton Friedman lo ha expresado de manera muy clara:

Vistos como un medio para el fin de la libertad política, los, arreglos económicos son importantes por sus efectos en la concentración o dispersión del poder. El tipo de organización económica que proporciona libertad económica directamente, es decir, el capitalismo competitivo, promueve también la libertad política porque separa el poder económico del poder polftico y, con ello, permite que el uno compense al otro.

La evidencia historica habla al unísono por lo que respecta a la relación entre libertad política y mercado libre. No conozco ningün ejemplo en el tiempo y en el espacio de una sociedad caracterizada por una gran dosis de libertad política que no haya utilizado algo comparable a un mercado libre para organizar el conjunto de su actividad económica. ${ }^{56}$

\section{$\mathrm{Y}$}

[...] la gran ventaja del mercado es [...] que permite la diversidad. Dicho en términos políticos, es un sistema de representación proporcional. Es como si cada hombre pudiera votar por el color de la corbata que quiere y obtenerla; no tiene que ver cuál es el color que la mayoría prefiere y, si está en minoría, aceptarlo.

$[\ldots]$

El poder económico puede ser dispersado ampliamente. No hay ninguna ley de conservación que fuerce el crecimiento de nuevos centros de fuerza económica a expensas de los centros existentes. [...] Por otra parte, si el poder económico es mantenido en manos diferentes de las que tienen el poder político, puede servir para controlar y contrarrestar el poder político.5?

Al no exigir la conformidad colectiva en relación a las decisiones o preferencias sobre las cuales los individuos no están de acuerdo, el mercado contribuiría a disminuir las tensiones sociales. Sólo el mercado garantizaría la unanimidad; esto significa que una sociedad en la que la mayor parte de los asuntos colectivos es solucionada por la vía mercantil tiene más probabilidades de asegurar el ejercicio de las libertades individuales que aquella en la que las decisiones son impuestas por el Estado. Mercado y Estado se presentan como dos polos de decisiones: el primero representaría la armonía y el consenso; el segundo, sería el ámbito de la imposición y del conflicto. Aceptada esta premisa, no cuesta inferir que a mayor mercado mayor libertad individual. Si la democracia es la forma de gobierno que garantiza el mayor ámbito de libertad individual posible en un contexto social, es obvio que existe también una relación directa en- 
tre mercado y democracia: todo intento de intervención en el libre juego del mercado afectaría negativamente a la democracia.

Por ello, la crítica neoliberal sostiene que el "fracaso del Estadon es una consecuencia del «fracaso del mercado", es decir, de la «distorsión del mercadon a raíz de las limitaciones impuestas por la planificación social, es decir, por esquemas redistribucionistas. Como toda redistribución significaría una violación de los derechos de propiedad individual, este fracaso implicaría el peligro de que, al final, cayese también el tercer soporte del clásico edificio de mercado, Estado y ciudadano soberano, es decir, la libertad individual. Esta es la tesis de la pérdida de la libertad, con la que se ha querido apoyar la ofensiva contra el Estado social de derecho.

\subsection{Análisis critico de las justificaciones éticas del mercado}

Veamos más de cerca estos argumentos. Comencemos con las justificaciones deontológicas.

Con respecto a 2.1.1.1:

Por lo que respecta al teorema directo, no cuesta mucho encontrar situaciones en las que puede estar asegurado un equilibrio competitivo y que, sin embargo, sean inaceptables desde el punto de vista ético.

La debilidad ética del teorema directo puede ser explicada desde diversos enfoques. Uno de ellos consiste en afirmar que ella es la consecuencia de considerar que el consenso fáctico es una instancia definitoria suprema de lo bueno. Tiene razón Buchanan cuando afirma que no conviene jugar a ser Dios en el campo de la ética; pero, de aquí no se infiere que la única alternativa sea el recurso al consenso fáctico. La aplicación consecuente del criterio del consenso fáctico tiende a la autodestrucción de la libertad individual, que era justamente el punto de partida de esta justificación deontológica del mercado. Baste pensar en los contratos de esclavitud que, con razón, preocupaban a John Stuart Mill y le obligaban a introducir limitaciones en su enfoque utilitarista. Sobre la propuesta del consenso fáctico como base de legitimidad volveré en la conferencia siguiente. Aquí quiero tan sólo subrayar un peligro de autodestrucción.

El teorema directo plantea también problemas con respecto al valor de la igualdad. Ciertamente, como ha observado Amartya Sen, el hecho de que tal sea el caso, no es argumento suficiente para desecharlo pero, si...

[...] el teorema directo ha de ser considerado como uno de gran relevancia ética, se nos tiene que decir algo más acerca de la irrelevancia moral general de la desigualdad de bienestar o acerca del caso moral de las desigualdades particulares que contingentemente ocurririan en cada caso..$^{58}$ 
Siguiendo una sugerencia de Brian Barry, puede establecerse una distinción entre el principio de Pareto y los principios liberales. Aquél se referiria a la bondad de un estado de cosas y estos últimos a los derechos que deben ser asignados a los individuos. El no haber tenido en cuenta esta distinción sería la causa de inferencias apresuradas y de no pocos malos entendidos..$^{59} \mathrm{La}$ aplicación consecuente del teorema directo conduce en este caso a la destrucción de la igualdad.

El teorema converso deja abierta la posibilidad de establecer condiciones éticamente aceptables para el ingreso al mercado. Una vez aseguradas éstas, podría el mercado funcionar sin intervenciones políticas. Esta versión es, desde luego, más aceptable que la del teorema directo, pero ello se debe justamente a que el mercado queda sujeto a restricciones iniciales. Esta es la posibilidad que también tuvo en cuenta posteriormente Buchanan, al admitir no sólo la relevancia del punto de partida de la negociación en el mercado sino también de las medidas redistributivas:

En la medida en que los jugadores entran en el juego en condiciones aproximadamente iguales y tienen la oportunidad de jugar de acuerdo con las mismas reglas, las reglas son "equitativas" en un sentido muy fundamental y básico [...] Pero, los preceptos de equidad, interpretados más extensivamente, pueden sugerir alguna redistribucion post-produccion. Es decir, aun si los valores esperados de todas las participaciones de ingreso deben ser iguales ex ante, la distribución actual de las participaciones ex post puede presentar una diferencia tal como para que esté impuesto su rechazo por razones contractuales. ${ }^{* 0}$

Pero, aun cuando se deje de lado la cuestión de la redistribución postproducción, queda en pie el problema de saber cuál es la distribución correcta inicial. Para lograrla, haría falta tener información acerca de lo que Buchanan llama el make-up psicológico de cada cual (gustos, preferencias) y de la capacidad productiva de cada cual. Si se trata de personas egoístas, no es plausible suponer que ellas estén dispuestas a proporcionar esta información si es que saben que con ello pierden sus ventajas en el juego mercantil. Para evitar las posibles consecuencias negativas de la aplicación del teorema converso, quien distribuye las dotaciones iniciales tendría que ser omnisapiente. Por ello sostiene Gibbard (siguiendo a Ronald Dworkin) que el problema de la justicia económica se convierte en un problema de seguros: como la vida es insegura, una persona prudente debería procurar asegurarse frente a las grandes calamidades de la vida. Un mercado que funcionase exclusivamente sobre la base de la aplicación del teorema converso terminaria destruyéndose a sí mismo, al ir provocando la expulsión de quienes ingresan en el mercado con una deficiente dotación de bienes.

Con respecto a 2.1.1.2:

La tesis central de Nozick sostiene que aun cuando los individuos no lo desearan expresamente, a la larga habrá de surgir un Estado que, si 
desea respetar la individualidad moral de las personas, necesariamente tendrá que ser no redistributivo. La explicación de este proceso genético se basa en la acción de la llamada mano invisible que guía a las personas, a través de asociaciones protectoras que funcionan como compañías de seguros que defienden a sus clientes frente a ataques de terceros, hasta el Estado mínimo que, de facto, aunque no de iure, detenta el monopolio de un poder adquirido sin violar el principio moral de la autonomía individual, gracias al principio de indemnización material a quienes se niegan a renunciar a su derecho a practicar la justicia privada. Hasta qué punto el principio de indemnización es conciliable con una actitud antipaternalista y en qué medida el principio de libertad ha sido sustituido por el de solidaridad es algo que conviene ya tener en cuenta, desde el momento en que ello significaría el fracaso de la empresa que se había impuesto Nozick: la intención libertaria tendría consecuencias no deseadas que apuntarían a un Estado social de derecho.

Pero, aun cuando dejemos de lado este aspecto de la cuestión, surge un problema que considero más significativo: en la versión de Nozick sobre el surgimiento del Estado mínimo, éste posee el monopolio del poder tan sólo de facto. Es una institución fáctica con la que tienen que contar los ciudadanos. A la larga, de esta constelación de Estado y ciudadanos no habrá de surgir ninguna legitimidad ya que en toda formación estatal legítima, están claramente definidas las posibilidades de ingerencia institucional; en cambio, en un poder de facto, se borran los límites entre lo constitucionalmente permitido y las posibilidades situacionales de conformación política. Esto coloca a los afectados en una situación de gran inseguridad, ya que los ciudadanos carecen de una instancia a la que pudieran recurrir en caso de ataques del Estado. En la versión de Nozick, cada cual conserva su derecho a la justicia privada, aunque de facto no pueda ejercerla. Según Nozick, ésta es una solución especialmente elegante porque lo libera de la objeción de que dota al Estado de competencias jurídicas especiales, algo que estaría moralmente prohibido en una concepción radicalmente individualista. Pero esta constelación no asegura una relación no conflictiva entre el Estado y los ciudadanos, de la que pudiera surgir una posible legitimidad sino que, subrepticiamente, va creando una relación de coacción autoritaria entre el Estado y los ciudadanos. La concepción de Nozick, si se la aplica coherentemente, conduce a un Estado paternalista con respecto a quienes no quieren ingresar en el Estado ultramínimo y al uso permanente del principio de corrección de las transferencias de propiedad por parte del Estado mínimo. No deja de ser significativo, en este sentido, que el propio Nozick tenga que admitir que "los puntos de vista por mí rechazados de la justicia distributiva y de la igualdad pueden jugar un papel».

Sobre la propuesta neoliberal que sigue el lema «cuanto menor Estado, mayor libertad individual», habré de volver en la tercera de estas con- 
ferencias. Baste aquí señalar que Hans-Peter Müller ${ }^{61}$ ha demostrado con argumentos, en mi opinión convincentes, que más plausible resulta la tesis de Durkheim según la cual «Plus l'État est fort, plus l'individu est respecté». La idea de Durkheim es que la institución Estado fuerte está en condiciones de defender mejor la libertad individual, siempre que la acción del Estado esté enmarcada dentro de ciertas condiciones.

En el caso de los enfoques pragmáticos, si llega a demostrarse que no se da la relación causal necesaria entre el establecimiento del mercado y la libertad de elegir o la promoción de la eficiencia, quien adopte la vía de la justificación pragmática tendrá que estar dispuesto a aceptar ciertas limitaciones que resultan del carácter contingente de sus méritos.

Detengámonos en estos argumentos.

Con respecto a 2.1.2.1:

Un aspecto relevante en este teorema de Coase es lo que podría llamarse versión radical de la commodifying of rights, es decir, considerar que los derechos son factores de producción y, por lo tanto, pueden ser intercambiados, vendidos y comprados.

La versión de Coase conduce a ignorar el principio liberal en el que con tanto vigor insistiera Mill, es decir, el principio de daño a terceros. La tesis de Coase afirma que si la distribución de derechos no afecta la optimalidad del mercado, entonces es indiferente para la formulación de politicas quién sea el autor del daño originario..$^{62}$

Lo relevante sería el costo que la prevención del daño puede causar en los mecanismos de producción. Es obvio que de esta manera es posible justificar las formas más radicales de explotación y llegar a la situación éticamente grotesca de la puesta en duda de toda autodefensa hasta tanto se hayan aclarado los costos de producción que ella implica.

Sobre los argumentos de la eficiencia pesan, en general, todas las objeciones que se han hecho valer en contra de los argumentos utilitaristas: desde el no tomar en cuenta la índividualidad y separabilidad de las personas, hasta la imposibilidad de dar una solución satisfactoria al problema de las llamadas "conductas parasitarias" y a las cuales me he referido en la conferencia anterior.

Con respecto a 2.1.2.2:

Según Allan Gibbard:63

Los bellos resultados de la mano invisible se producen sólo si se dan ciertas condiciones idealizadas: que todo lo que importa en la vida procede del consumo privado de bienes; que la información es perfecta, los bienes infinitamente divisibles y los agentes económicos perfectamente racionales.

En los mercados reales, no se dan estas condiciones idealizadas: los costos de las transacciones no son nunca iguales a cero sino que hay que 
tener en cuenta los costos de comunicación, información y de control jurídico. Estos últimos resultan del propio comportamiento de los individuos en el mercado real y de la creación del Estado, aun en la forma mínima del Estado protector de Buchanan o de Nozick. $Y$ hay que tomar en cuenta, desde luego, la cuestión de las llamadas externalidades, es decir, de los efectos negativos o positivos con respecto a terceros que no participan en una transacción. La existencia de estas externalidades parece requerir una intervención del Estado mucho más amplia que la que podría aceptar un defensor neoliberal del mercado. La propuesta de solución de Coase con respecto a la externalidad negativa de la fábrica contaminante no parece satisfacer requisitos mínimos de justicia.

Las externalidades negativas del mercado se manifiestan también -como lo ha observado Carlos S. Nino- ${ }^{64}$ en la producción de los bienes públicos y en el problema de los free riders (colados o gorrones):

Todas estas fuentes de ineficiencias del mercado parecen justificar una amplia intervención estatal, para superar los costos de transacción, superar la falta de información, reprimir los monopolios, establecer límites a la acción mediante penas, impuestos o servicios públicos para impedir los efectos de las externalidades positivas y negativas y permitir la provisión de bienes públicos $[\ldots]^{65}$

La creación de externalidades inevitables constituye una especie de cáncer alimentado por la propia actividad mercantil, sobre cuya peligrosidad autodestructiva pienso que no es necesario insistir.

Con respecto a 2.1.2.3:

Allan Gibbard ha observado, en mi opinión con razón, que lo que se necesita para que cada cual pueda elegir diversos cursos de vida es, desde el punto de vista económico, por lo pronto, un sistema de precios. Pero un sistema de precios no tiene por qué surgir únicamente de un sistema puro de intercambio libre. También existe este sistema en economías controladas estatalmente. Además, la puesta en práctica de la forma de vida elegida no depende exclusivamente del sistema de precios sino también de la capacidad adquisitiva de las personas y ello es algo que un sisterna puro de mercado no puede asegurar.

La insistencia unilateral de Friedman o de Machan en el valor de la libertad negativa se basa en la creencia de que sólo existen deberes negativos y que todo deber positivo implica la imposicion de un acto supererogatorio. Pero, cuando la libertad negativa no va acompañada de la libertad positiva, aquélla termina siendo impotente para garantizar la autonomía de la persona. Sobre este punto volveré más adelante.

Con respecto a 2.1.2.4:

Por lo que respecta a la relación entre mercado y democracia, pienso que es falso sostener que el mercado es condición suficiente para que 
exista la democracia. Por ello, tiene razón James Fishkin cuando subraya la...

[...] contingencia histórica de que las exigencias de libertad política y de ciertas libertades económicas surgieron juntas. Sin embargo, esta explicación contingente deja abierta la posibilidad teorica de que las libertades políticas puedan ser separadas de las libertades económicas vinculadas con el mercado [...].66

En la versión de algunos neoliberales parecería estar presente la concepción de la existencia de una relación de condicionamiento suficiente entre mercado y democracia. Pienso que no cuesta mucho demostrar la falsedad de esta tesis. Basta pensar en los ejemplos de dictaduras cọn mercado cual es el caso de la España de Franco, del Chile de Pinochet o de la Argentina de Videla. Pero, el rechazo de esta tesis fuerte no implica la negación de una tesis más débil, es decir, la que sostiene que el mercado es condición necesaria, aunque no suficiente, de la democracia. En lo que sigue habré de suponer que tal es el caso, en cuanto puede permitir un mayor despliegue de la autonomía individual para la producción y adquisición de bienes de consumo. Dejo de lado, pues, el problema de los bienes públicos, cuya producción requiere la presencia de un Estado cuya función no se agota en la protección de la libertad negativa.

En la versión clásica del laissez-faire, la libertad para elegir que ofrece el mercado sería una de las formas más eficaces para asegurar el respeto a la autonomía individual. El consumidor sería el verdadero soberano que decide sobre qué debe producirse. Con palabras de Adam Smith:

El objetivo y fin de toda producción es el consumo y los intereses del productor deben ser tenidos en cuenta sólo en la medida en que ello sea necesario para la promoción de los intereses del consumidor. Esta máxima es intuitivamente tan clara que sería de mal gusto querer demostrarla. ${ }^{67}$

En versiones más actuales de la libertad de mercado, formuladas por investigadores sociales que difícilmente pueden ser catalogados como neoliberales, como Oppenheim, se insiste en las relaciones de poder simétrico recíproco entre vendedor y consumidor. Si ello es así, no hay duda que la mejor forma de reducir la imposición de decisiones heterónomas es la aceptación de las reglas del mercado libre.

No se trata, pues, de aceptar las justificaciones deontológicas del mercado sino de admitir, dentro de las justificaciones pragmáticas, su relevancia para la democracia representativa. Lo que me importa subrayar es su valor instrumental, de la misma manera que la democracia representativa tiene un valor instrumental con respecto al respeto de la autonomía y la igualdad individuales. 


\subsection{La tendencia del mercado a su autodestrucción}

Todo andaria bien, si en la marcha del mercado no volvieran a presentarse tendencias autodestructivas muy similares a las que vimos en la conferencia anterior en el caso de la democracia representativa. Para alguien que, como yo, no es economista y su interés sobre los problemas del mercado se centra en aquellas cuestiones que tienen relevancia para la justificación ética de la vida en sociedad, una vía que parece plausible para estudiar el funcionamiento real del mercado es recurrir a autores como, por ejemplo, Walter Eucken, quien, desde luego, no está pensando en el tema del suicidio institucional que aquí nos ocupa y, sin embargo, en sus Grundsätze der Wirtschaftspolitik, presenta un cuadro clínico muy parecido al que expuse en mi primera conferencia sobre la democracia. Tal vez sea ilustrativo recordar algunas de sus tesis confirmadas con abundantes datos empíricos:

Son las siguientes:

1) Tanto los productores como los consumidores procuran, siempre que ello es posible,

[...] evitar la competencia y adquirir o afianzar posiciones monopólicas. En todos los ticmpos ha habido un fuerte impulso para eliminar la competencia y adquirir el monopolio. [...] Existe universalmente una uinclinación a la formación de monopolios", un hecho que debe tener en cuenta toda política econónica. ${ }^{68}$

El diagnóstico de Eucken es totalmente opuesto al de Friedman: el mercado no tiende a la dispersión del poder sino a su concentración.

2) Esta tendencia a la creación de monopolios tiende a anular el esfuerzo individual para lograr un mayor rendimiento:

La competencia de rendimiento se parece a una carrera. El esfuerzo paralclo deberia aumentar el rendimiento individual y en la meta deberian decidir los consumidores. [...] Pero, en las luchas por el monopolio no decide el rendimiento para los consumidores sino la fuerza de la posicion de poder existente. [...] La lucha por el monopolio no sólo es diferente a la lucha por el rendimiento sino que la impide. Este es un hecho de considerable importancia jurídico-política y económico-política. Aquí se enredó la política económica liberal del siglo xIx y comienzos del $\mathrm{xx}$ : otorgó libertad para la lucha por el monopolio y contribuyó, de esta manera, a desplazar a segundo plano la competencia por el rendimiento, que era justamente lo que no queria que sucediera ${ }^{69}$

3) La libertad incontrolada del mercado tiende a destruir la libertad individual: 
La libertad económica tiene para estos políticos de la economía Llos partidarios del laissez-faire, E.G.V.] una doble importancia: ella es el fundamento de la vida personal humanamente digna del individuo y ella posibilita, al mismo tiempo, que se realice el plan de la creación del que resultan determinadas leyes naturales de la cconomía. Pero el desarrollo fáctico mostró que, por ambos costados, esta política económica no alcanzó aquello que quería. Se comprobó que el otorgamiento de la libertad puede ser un peligro para la libertad cuando posibilita la formación del poder privado, que ciertamente despierta fuerzas extraordinarias pero que estas energlas pueden actuar destruyendo la libertad. Y que también un orden natural no surge simplemente si la política económica deja librada su realización al desarrollo sino sólo cuando ella está dirigida a tal fin. ${ }^{70}$

Si se admite, pues, que el mercado es condición necesaria de la democracia y se acepta también como verdadera esta tendencia del mercado a su autodestrucción en virtud de la proclividad a la creación de monopolios, nos encontramos ahora con la nada alentadora comprobación de que las tendencias suicidas de la democracia resultan reforzadas.

Posiblemente hemos llegado a este resultado por habernos limitado a considerar sólo aspectos formales del funcionamiento de la democracia representativa y del mercado. Esto sugiere la conveniencia de buscar resguardos normativos adicionales y nos remite al problema de la legitimidad de los ordenamientos políticos y a lo que habré de llamar la "cuestión de las circunstancias del mercadon.

José Luis Aranguren ha señalado que «El Estado modemo no puede ser éticamente neutral", ${ }^{71}$ En las dos próximas conferencias me propongo tomar en serio esta afirmación y analizar las vías posibles de la superación efectiva de la neutralidad ética del Estado. Si ello se logra, pueden también encontrarse frenos a las tendencias suicidas de dos instituciones que, en su núcleo, son fundamentales para el aseguramiento y la promoción de la autonomía y la igualdad individuales.

\section{El control de la democracia}

En vista de los problemas presentados en las dos conferencias anteriores, conviene detenerse a analizar ahora propuestas de solución. Pienso que las mismas están estrechamente vinculadas con la cuestión de la legitimidad de los sistemas políticos. Si ello es así los frenos al suicidio tendrán que ser -como trataré de exponerlo en esta conferencia y en la siguiente- de naturaleza ética. Volvamos pues sobre los problemas presentados en las conferencias anteriores.

Dos eran los problemas vinculados con el ejercicio de la democracia representativa: el de la limitación del soberano y el de la tendencia a practicar comportamientos parasitarios. Quiero referirme a ellos por separado. 


\subsection{La timitacion del poder soberano}

Con respecto al problema lógico de la dificultad de limitar jurídicamente al soberano, podría pensarse en la conveniencia de distinguir dos tipos de soberanos: uno realmente absoluto en sentido fuerte, de autolimitación jurídica imposible, y al que en otros trabajos he llamado «soberano 0 n y otro que ejerce funciones delegadas y limitadas por el soberano $0 \mathrm{y}$ al que propongo llamar "soberano 1 ". En un sistema democrático parlamentario, aquél sería el "pueblo" (dejando de lado todas las dificultades que esta designación encierra) y este último sería el parlamento jurídicamente limitado por la Constitución.

Un claro ejemplo de este tipo de limitaciones es el artículo 173 de la Constitución de Cádiz de 1812 referido al juramento que deberá prestar el monarca en su advenimiento al trono. Reza así:

$Y$ si en lo que he jurado o parte de ello, lo contrario hiciere, no debo ser obedecido; antes aquello en que contraviniere, sea nulo y de ningún valor.

Esta frase recuerda a la de Ulises que mencionara en la primera conferencia. La diferencia reside en que en el caso de Ulises suponía que la frase la pronunciaba un soberano 0 mientras que aquí quien la dice es un soberano 1 y, por lo tanto, ya no vale la objeción del cumplimiento imposible.

Si se quiere recurrir a un ejemplo actual, puede pensarse en el artículo 79, párrafo 3 de la Ley Fundamental alemana que dice:

No está permitida una modificación de esta Ley Fundamental que afecte la organización de la Federación en Estados federados, la participación básica de los Estados federados en la legislación o los principios establecidos en los artículos 1 y 20.

Si el artículo 173 de la Constitución de Cádiz establecía la nulidad de lo ordenado violando el juramento, la Ley Fundamental alemana incluye en el artículo 20, párrafo 4 el derecho de resistencia para los casos de violación del artículo 79 , párrafo 3 . Su texto es el siguiente:

Cuando no exista ningún otro medio, todos los alemanes tienen el derecho de resistencia contra aquel que intente derribar este orden.

Como es sabido, el párrafo 3 del artículo 79 de la Ley Fundamental fue introducido como garantía frente a futuros despotismos similares a los sufridos en la Alemania nazi. Es interesante recordar con respecto al tema que nos ocupa una frase de uno de los más conocidos constitucionalistas alemanes, Konrad Hesse. De lo que se trataba era de... 
[...] evitar el suicidio de la democracia del Estado de derecho bajo la forma de la legalidad $[\ldots] .^{72}$

Para una mejor comprensión de las disposiciones constitucionales a las que aquí me refiero, conviene tener en cuenta que el artículo 1 de la Ley Fundamental se refiere a la protección de la dignidad de la persona y el 20 en sus párrafos 1, 2 y 3 establece que la República Federal de Alemania es un Estado democrático y social, que todo poder emana del pueblo, quien a través de elecciones designa a sus representantes, que la legislación debe atenerse a la Constitución y los poderes ejecutivo y judicial a la ley y al derecho.

Esta restricción al soberano 1 pone de manifiesto que se trata de una cuestión tan importante que su tratamiento no puede quedar en manos de la simple mayoría parlamentaria.

Robert Alexy ${ }^{73}$ ha expresado este problema de la siguiente manera:

La concepción formal de los derechos fundamentales expresa un problema esencial [...] en un Estado democrático. Las normas iusfundamentales que, como las de la Ley Fundamental, vinculan al legislador, establecen lo que debe y lo que no puede decidir el legislador legitimado democráticamente. Desde su perspectiva, fijan prohibiciones y mandatos que limitan su libertad y [...] su competencia. En este sentido, se produce necesariamente una colision entre el principio de la democracia y los derechos fundamentales. El que, por otra parte, el principio de la democracia exija la existencia de una serie de derechos fundamentales (por ejemplo, derecho electoral, libertad de opinión), no altera en nada esta colisión sino que muestra que el principio de la democracia tiene que ser dividido en varios subprincipios que pueden entrar en colisión recíproca lo que, dicho sea de paso, constituye el fundamento teórico-normativo de la llamada paradoja de la democracia, que apunta al viejo problema de la eliminación democrática de la democracia. La necesaria colision entre el principio de la democracia y los derechos fundamentales implica que el problema de la distribución de competencias entre el legislador parlamentario legitimado democrática y directamente [...] y el Tribunal Constitucional sólo indirectamente legitimado democráticamente $[. .$.$] es un problema insoslayable$ y permanente.

\subsubsection{Las limitaciones extraconstitucionales}

No quiero detenerme en mi propuesta de las limitaciones juridicas al soberano $1 \mathrm{y}$ en la practicabilidad de un derecho positivo de resistencia, cuestiones a las que me he referido extensamente en otro trabajo. ${ }^{74}$ Aquí deseo centrar mis consideraciones en el origen de estas limitaciones. No hay duda que ellas son introducidas por los constituyentes. La cuestión es saber cuál es el fundamento de su legitimidad. Si no se quiere caer en un círculo vicioso, la respuesta no puede ser que estas limitaciones poseen legitimidad por estar incorporadas a la Constitución. El problema es saber cuál es su fundamento extraconstitucional, es decir, ético-político. Veamos las propuestas más importantes. 
Podría pensarse que la solución debe buscarse o bien en situaciones fácticas o bien en situaciones hipotéticas de los miembros de una determinada sociedad.

3.1.1.1. Consenso fáctico y legitimidad. Entre las teorías que adoptan como marco para el análisis de la legitimidad la situación fáctica de los miembros de una determinada sociedad pueden mencionarse la de Niklas Luhmann, la de Jürgen Habermas y la de James S. Fishkin.

I) Como es sabido, según Luhmann, cada sistema político instituye, a través de un procedimiento específico para la adopción de sus normas y decisiones, sus propios fundamentos de legitimidad o legitimación (ambos términos son utilizados indistintamente por este autor). La aceptación rutinaria de los resultados obtenidos por el procedimiento sería condición necesaria y suficiente para la legitimidad del sistema. Cuáles sean las razones por las que los miembros de un sistema político aceptan las decisiones sería irrelevante. Se podría hablar, en este sentido, de motivaciones «en bruto». Lo importante es que exista un consenso básico de aceptación del procedimiento. Con palabras de Luhmann:

El sistema político tiene que poder combinar motivaciones incompatibles del más diverso tipo e igualarlas de manera tal que se produzca casi una aceptación no motivada, evidente, de las decisiones obligatorias. ${ }^{75}$

$\mathrm{O}$

La incuestionabilidad de la validez legítima de las decisiones obligatorias es una de las características típicas del sistema político moderno, como una especie de consenso básico, que puede ser logrado sin que exista acuerdo acerca de lo que es objetivamente correcto en el caso particular, y que estabiliza el sistema. ${ }^{76}$

La tesis de Luhmann del consenso fáctico con independencia de la génesis de las motivaciones que conducen al mismo deja expuesta su teoría de la legitimidad a fuertes objeciones que no he de entrar a analizar aquí. Quiero tan sólo mencionar dos de ellas: la del positivismo ideológico y la de la indoctrinación o manipulación. El positivismo ideológico permite justificar autorreferencialmente cualquier sistema político. La afirmación de la existencia misma de un sistema político equivaldría a un juicio de legitimidad. Y como no importa la génesis de las motivaciones del consenso, no está excluida la posibilidad de la manipulación de quienes deben prestarlo, es decir, no está excluida la posibilidad de un paternalismo extremo que mantenga a los ciudadanos en situación de infantilismo cívico. Ninguna de estas dos consecuencias es muy atrayente si se quiere disponer de un criterio de legitimidad que no se limite a estipular las condiciones necesarias y suficientes para la existencia de un sistema político. 
II) Jürgen Habermas parte igualmente de la situación del consenso fáctico. Quienes participan en el discurso comunicativo son los miembros de la sociedad que son quienes juzgan acerca de hasta qué punto las estructuras políticas y sociales existentes deben ser mantenidas y reconocidas:

La imposición duradera de una norma depende también de que en un contexto dado [...] putedan movilizarse razones suficientes para que en el circulo de sus destinatarios su pretensión de validez pueda presentarse, al menos, como justificada. Aplicado a las sociedades modernas esto significa: sin legitimidad, ninguna lealtad de las masas. ${ }^{77}$

Pero, a diferencia de Luhmann, Habermas enmarca este consenso fáctico con condiciones trascendentales a fin de asegurar una situación ideal de discurso. Es esta referencia a una situación ideal lo que permite una lectura doble de Habermas: la de la situación fáctica y la de la hipotética.

En todo caso, quedan pendientes no pocas cuestiones vinculadas con el carácter ambiguo de la situación en la que ha de lograrse el consenso: si se trata de una situación fáctica, no hay duda que el tiempo juega un papel fundamental, asi como también el nivel de información y de interés de los participantes en llegar a una solución que tome en cuenta exclusivamente el bien común. Si se parte de una situación fáctica, ¿cómo puede pasarse de la voluntad de todos (mero consenso fáctico) a la voluntad general (consenso bajo condiciones trascendentales hipotéticas)?

Y queda también pendiente la cuestión de saber cómo ha de lograrse en una situación fáctica la vigencia efectiva de las condiciones del discurso ideal habermasiano. A través de la discusión racional, ello parece más que problemático en virtud de la experiencia histórica, que permite inferir una probabilidad muy reducida de renuncias voluntarias a privilegios que contradicen la situación de igualdad presupuesta en el discurso de comunicación ideal. ¿Estarían entonces autorizadas formas de acción colectiva no consensuales para la obtención de esta situación ideal de discurso? ¿O se trata más bien en el caso de esta última de una situación hipotética que proporcionaría criterios de evaluación acerca de la justicia o injusticia de una situación fáctica? Si se acepta esta segunda sugerencia, entonces la teoría de Habermas tendría que ser catalogada entre las que proponen un consenso hípotético y a las que he de referirme un poco más adelante.

III) Una tercera ilustración de la adopción de un punto de partida fáctico, pero con motivaciones «filtradas», es la ofrecida por James S. Fishkin con su noción de «cultura política autorreflexiva»:

La premisa de mi argumento constructivo es que las justificaciones de la autoridad del Estado tienen que estar dirigidas a aquellos que tienen que vivir bajo tal autoridad, a aquellos que tienen que vivir con la pretensión, habitualmente respal- 
dada con un enorme poder, de que los innumerables efectos negativos del Estado en nuestras vidas cotidianas están plenamente justificados. La primera cuestión que hay que plantear acerca del Estado no es si hemos «consentido" a él en algún sentido (tácito, expreso, hipotético o de algún otro tipo). Más bien de lo que se trata es si el Estado nos ha permitido estar en una situación en la que nos es posible, en alguna manera razonable, evaluarlo [...] La primera cuestion de la filosofía política es si la forma de cultura política que es tolerada o propiciada en un Estado dado es una que permite a quienes están sujetos a su autoridad evaluarla, determinar desde adentro, si la autoridad a la que ellos están sometidos es justificable. ${ }^{78}$

Según Fishkin, la evaluación acerca de si la autoridad es o no justificable se lleva a cabo de acuerdo con los argumentos que es racional aceptar dentro de la respectiva cultura política. Es la posibilidad de la autorreflexión la que permitiría evitar los peligros de la indoctrinación. Todo Estado que niegue a sus súbditos las condiciones necesarias para una "razonable evaluación de su propia autoridad [...] sin que importen cuales sean sus otros beneficios, se negaría a sí mismo la posibilidad de resolver el problema de la legitimidad.$^{79}$ Según Fishkin, lo decisivo es la existencia de las condiciones de evaluación, sin que importen los resultados de la misma.

Esta posición tiene aparentemente la ventaja de que elimina toda posibilidad de manipulación o de paternalismo. Es obvio que ésta es una buena vía para evitar la dictadura. La cuestión es saber si con ello se ha asegurado también la legitimidad del respectivo sistema político. Me inclino a creer que tal no es el caso.

En efecto, ¿podría sostenerse, por ejemplo, que un sistema político que satisface las conclusiones a las que llega la población con respecto a la conveniencia de practicar la antropofagia aplicada a las mujeres cuando su número supera ampliamente el de los hombres (esta población es estrictamente monogámica) ha solucionado cabalmente el problema de su legitimidad? Puede suponerse, para completar las condiciones de Fishkin, que el gobierno otorga a la población todas las posibilidades de autorreflexión y de información acerca de lo que sucede en otras sociedades en donde la antropofagia está estrictamente prohibida (no sólo con relación a las mujeres); el resultado es siempre el mismo: la población sigue propiciando en su inmensa mayoría (gracias al voto de las mujeres casadas autorreflexivas y de las solteras que prefieren correr el riesgo del asador al de la infidelidad del posible marido, provocada por un exceso de solteras) la antropofagia femenina. Supongamos ahora que sube al trono un nuevo rey, Filógeno I quien, tras largas meditaciones, llega a la conclusión de que no hay ningún argumento racional que permita la antropofagia femenina $y$, por ello, resuelve prohibirla. Además, para evitar que incorregibles amantes de la carne femenina (bajo la inaceptable forma de la antropofagia, claro está) intenten mantener viva una tradición ćticamente reprochable, prohí- 
be también que se hable más del asunto, es decir, actúa dictatorialmente en este tema y comete el supuesto pecado de indoctrinación paternalista. ¿Diríamos en este caso que el sistema ha perdido legitimidad porque ya no cuenta con el consentimiento fáctico y autorreflexivo vigente en la cultura política de su sociedad?

A quien considere que el ejemplo de Filógeno I es poco adecuado - por inverosímil - para poner de manifiesto las perplejidades a que puede conducir el consentimiento fáctico cuando se lo acepta como condición suficiente de legitimidad, quizás lo convenzan estas sabias reflexiones de Francisco de Vitoria ${ }^{80}$ con relación a los sacrificios humanos en México:

No cs obstáculo el que todos los indios consientan en tales leyes y sacrificios, y que no quieran en esto ser defendidos por los españoles. Pues no son en esto dueños de sí mismos ni tienen derecho a entregarse a sí mismos y a sus hijos a la muerte.

Tanto el ejemplo de Filogeno I como la cita de Vitoria inducen a pensar que no es posible inferir sin más del consentimiento fáctico la legitimidad de un sistema político. El consentimiento fáctico es, sin duda, la expresión más confiable de los valores vigentes en una determinada sociedad. De él se infiere el contenido de la moral positiva de aquélla, es decir, si se quiere utilizar una expresión de H.L.A. Hart: el punto de vista intemo de los miembros de una sociedad con respecto a las normas que deben regirla. Pero este punto de vista interno es insuficiente para juzgar acerca de la legitimidad, si es que ella ha de ser entendida como coincidencia de los principios y reglas vigentes en una sociedad política con los principios y reglas no ya de una moral positiva sino de una moral esclarecida o ética.

3.1.1.2. Consenso hipotético y legitimidad. En vista de los problemas que plantea el consenso fáctico, podría pensarse que la salida estâ en buscar como punto de partida no una situación real sino hipotética.

También aqui quiero mencionar brevemente tres posiciones.

1) James Buchanan ha propuesto un modelo de justificación del Estado sobre la base de un consenso racional e hipotético sujeto tan sólo al respeto de la individualidad de cada cual. Esta individualidad está definida por el marco de los derechos de cada cual en una situación de "distribución natural» a la que se llega invirtiendo esfuerzos del más diverso tipo (fuerza física, astucia, inteligencia, engaño). No obstante el heterogéneo origen de esta distribución natural, los individuos encontrarán racional, según Buchanan, ${ }^{81}$ aceptar consensualmente un contrato constitucional que evite los gastos improductivos de ataque y defensa:

Cualesquiera que puedan ser las características de esta distribución, sea que prevalezca una simetría aproximada o que uno de los participantes se convierta en 
un gigante del consumo y el otro en un pigmeo [...] ambas partes estarán mejor si se logra llegar a un acuerdo.

Como esta situación de distribución natural es compatible con las mayores desigualdades, puede suceder, desde luego, que sea conveniente para las partes contratantes firmar un contrato de esclavitud:

La eliminacion completa de otras personas puede no ser, sin embargo, el curso de acción preferido por quienes posecn capacidades superiores. Un estado más preferido aún puede ser aquel en el cual a quienes son "débiles» se les permite que realicen esfuerzos para producir bienes, de los cuales después los ofuertes" se apoderan [...] para su propio uso. En esta situación, el contrato de desarme que es negociado puede ser similar a un contrato de esclavitud en el cual el adébil" produce bienes para el «fucrte» a cambio de conservar algo más que la mera subsistencia, que puede ser incapaz de asegurar en la situación de anarquía. Un contrato de esclavitud, al igual que los otros contratos, define derechos individuales $\mathrm{y}$, en la medida en que esta asignación es mutuamente aceptada, pueden asegurarse ganancias mutuas de la reducción consiguiente de los esfuerzos de defensa y depredacion. ${ }^{\text {sz }}$

Este contrato de esclavitud celebrado en la situación hipotética de "distribución natural» sería además «bueno», y por lo tanto legítimo, ya que una situación es juzgada "buena" en la medida en que permite que los individuos obtengan lo que desean, cualquier cosa que ello sea, con la única condición del acuerdo mutuo. ${ }^{83}$

Parece difícil aceptar esta fundamentación racional y consensual del Estado originado en una situación hipotética en la que el mero consenso es fuente de legitimidad sin ninguna otra limitación normativa que la del respeto a la individualidad plasmada a través de la distribución natural.

II) Un paso hacia la imposición de limitaciones normativas más fuertes en la situación hipotética de consenso es el propuesto por David Gauthier. La limitación está dada en este caso por la cláusula cautelar de Locke, que prohíbe beneficiarse infligiendo un daño a otro. Esta cláusula es la que impide considerar como equitativo un contrato hipotético entre amos y esclavos. A diferencia de lo que sucede en Buchanan, para que sea racional aceptar una negociación, hay que eliminar las situaciones en las que una de las partes impone a la otra una coerción:

Argumentaremos que si el resultado no cooperativo implica coencion, entonces ésta tiene que ser reducida eliminando los efectos de esta coerción si es que ha de servir como posición inicial para negociar una estrategia conjunta que racionalmente exija el cumplimiento individual. ${ }^{84}$

La cláusula cautelar de Locke prohíbe la violación de deberes negativos pero no impone deberes positivos. La coacción a la que se refiere 
Gauthier es la que resulta del incumplimiento de aquéllos y no de estos últimos. En el caso de la propuesta de Gauthier, tampoco es relevante el origen de las motivaciones; lo único que importa es que las preferencias sean considered (ponderadas) pero, como señala Fishkin, ${ }^{85}$ este criterio no especifica nada acerca de las condiciones apropiadas para la formación de las preferencias y, por lo tanto, éstas no están libres del peligro de la manipulación. Según Gauthier:

Las preferencias son "ponderadas" si y sólo si no hay conflicto entre sus dimensiones de comportamiento y actitud, y son estables bajo la experiencia y la reflexion. ${ }^{86}$

La posición de Gauthier, al limitar la exigencia de "consideración» de las preferencias a la coherencia entre comportamiento y actitud, no excluye el problema de la indoctrinación o de un perverso paternalismo. Quienes en la sociedad medieval denunciaban a ciertas personas como brujas (de acuerdo con concepciones religiosas firmemente enraizadas) no presentaban ningún conflicto entre actitud y comportamiento; ${ }^{87}$ pero sería dificil inferir de ello una evaluación moral positiva de su comportamiento.

III) Finalmente, la teoría de John Rawls se basa en la propuesta de una situación hipotética como punto de partida para un consentimiento racional por parte de individuos cuyas motivaciones han sido "filtradas" a través del recurso del "velo de la ignorancia». En este caso no se dan ya problemas de indoctrinación pero sí los que Fishkin llama «institucionales":

La dificultad es que una vez que nos apartamos de la vida real, podemos apelar a cualquier número de situacioncs contrafácticas. Aun la menor diferencia por lo que respecta a la imparcialidad y la menor diferencia en las nociones de pretensiones o intereses relevantes en estas situaciones imaginarias conducen a resultados drásticamente diferentes. ${ }^{83}$

Y cabe, desde luego, preguntarse si la propuesta de un consenso entre los futuros miembros de una sociedad en una situación hipotética no constituye; como diría Hare, una dramatización inútil que no añade substancialmente nada al recurso clásico del observador imparcíal.

Ninguna de las seis posibilidades de fundamentación extraconstitucional de las limitaciones del soberano 1 , es decir, de justificación de un sistema político como legítimo resulta ser satisfactoria.

Podría pensarse que la insuficiencia de estos enfoques se debe a lo que hay de común en todos ellos, es decir, el aspecto del consenso o aceptación (sea fáctico o hipotético).

La falacia de la equiparación de consenso y legitimidad o, si se quiere, de consenso y justicia, está presente en todas las teorías que parten de lo 
que generalmente se llama "circunstancias de la justicia", es decir, aquellas teorías constructivistas que, partiendo de una situación original de desigualdad, avanzan hasta un punto óptimo situado en la curva de Pareto. Estas teorías no logran superar nunca la desigualdad inicial: su mérito consiste únicamente en un aumento de la eficiencia del sistema. Pero eficiencia no es lo mismo que justicia.

3.1.1.3. Disenso y legitimidad. En vista del fracaso de las propuestas consensualistas, ¿por qué no pensar en la alternativa del disenso?

Esta es la propuesta de Javier Muguerza para la fundamentación de los derechos humanos.

Un primer argumento que podría aducirse en favor de la alternativa del disenso es el de la experiencia histórica: la conquista de los derechos humanos. Ella wha tenido algo que ver con el disenso de individuos o grupos de individuos respecto de un consenso antecedenten. ${ }^{89}$ Dolf Sternberger ${ }^{90}$ ha ilustrado con buenos ejemplos el papel de los disidentes en el desarrollo de la emancipación social y en la formulación de los derechos humanos, desde las dos grandes revoluciones del siglo XVII hasta nuestros días. Pero, como el mismo Muguerza lo reconoce,"1 la historia presenta también abundantes contraejemplos. Los encomenderos disidentes no contribuyeron, por cierto, a la mejora de la condición humana del indio al lograr la derogación de las Leyes Nuevas, y no hay que olvidar que Hitler fue un disidente en Weimar. La historia da para todo.

Dejemos, pues, de lado las consideraciones históricas y centrémonos en las teóricas. Si se acepta que el disenso tiene, en tanto negación, que estar referido siempre a un consenso previo, cabe preguntarse de qué tipo de consenso se trata: fáctico o hipotético. $Y$ en ambos casos, la insuficiencia del consenso como fuente de legitimidad se transmite al disenso que lo niega: la calidad moral, tanto del consenso como del disenso, no puede derivar del hecho del consenso o del disenso, ya que la guillotina de Hume se encargaría de decapitar a quien quisiera argumentar por esta vía. Lo que hay que hacer es justamente seguir la vía inversa: justificar el consenso y el disenso desde una idea regulativa, desde un punto de vista moral, para el cual el imperativo de universabilidad y la actitud de imparcialidad ofrecen un buen apoyo.

Muguerza parece sentirse más atraído por la negación que por la afirmación. Su insistencia en la formulación negativa del imperativo categórico es una prueba de ello. La cuestión es saber si esta formulación negativa tiene alguna relevancia conceptual. Creo que no. Una prohibición de acción es traducible sin mayor problema en un mandato de omisión, es decir, en un imperativo afirmativo. No altera en absoluto el sentido de la versión negativa decir: «uno debe abstenerse de tratar a nadie como un medion, Y, si se admite que la distinción medio-fin es exhaustiva, ello equi- 
vale a decir «se debe tratar a todos como fines". La versión negativa no enriquece el contenido del imperativo. Mientras no se especifique en qué consiste tratar a alguien como un fin, tan vacía es la prohibición como la orden.

Pero, podría insistirse aún en la atracción de lo negativo y coincidir con Muguerza ${ }^{92}$ cuando afirma, siguiendo a Barrington Moore, que la disidencia surge del "sentido de la injusticia" y no del "sentido de la justicia». Fenómenos tales como las movilizaciones contra la guerra o la lucha de minorías oprimidas podrían ser interpretadas como manifestaciones de este "sentido de la injusticia». Sin embargo, una vez más, resulta difícil comprender qué aporta el prefijo negativo "in-» al sentido de la justicia. Sólo teniendo éste, puede uno sentir su violación o su ausencia en las situaciones concretas de la vida. Si los pacifistas no tuvieran un sentido de la calidad moral de la paz, sus manifestaciones serian realmente un $« \sin$ sentido".

Aun cuando no se aceptaran estas observaciones, lo que parece indiscutible es que no es la existencia del consenso o del disenso lo que fundamenta los derechos humanos o la legitimidad sino justamente al revés. Sostener lo contrario equivaldría a aceptar una especie de «alquimia del consensos ${ }^{93} \mathrm{o}$ del disenso, que transformaría los actos de voluntad de quien consiente o disiente en moralmente valiosos por el solo hecho de ser manifestaciones consensuales o disensuales. Sólo un consenso que respete los derechos humanos es éticamente aceptable. Lo mismo vale para el disenso. El hecho de que el consenso presuponga pluralidad de individuos o el disenso proceda "de una decisión tomada en la soledad de la conciencia ${ }^{94}$ no constituye una diferencia esencial entre ambos ya que también quien consiente puede prestar su consentimiento en virtud de una decisión tomada en la «soledad de su conciencia». Pero, en todo caso, queda en pic la incapacidad de ambos recursos para fundamentar los derechos humanos.

3.1.1.4. Heteronomía y legitimidad. Llegados a este punto, parece aconsejable invertir el razonamiento y pensar que la legitimidad de un sistema político no depende tanto de su génesis como del estatus moral de sus principios y reglas. Cabría, en este sentido, la imposición heterónoma de la legitimidad. Esto pone de manifiesto una diferencia esencial entre la soberanía de los Estados y la autonomía de las personas. El día que Sudáfrica derogó las normas del apartheid, ganó en legitimidad, por más que en la génesis de esta derogación pueda haber estado la presión extranjera, es decir, actos de intervención que no serían válidos en el caso de las personas. Pero, si esto es así, podría pensarse entonces que lo decisivo es la conformación del Estado y que para no equivocarse en la misma, nada sería más adecuado, para promover la autonomía de la persona, que la adopción de un Estado mínimo. 
Un caso paradigmático de esta propuesta es el de Robert Nozick. En estas conferencias, quería referirme tan sólo a dos aspectos: el del Estado mínimo como garantía de la libertad individual y el de la incorporación definitiva de todas las personas al Estado mínimo. Al primero me referí en la conferencia anterior; veamos, pues, ahora el segundo.

Como es sabido, en la etapa final del Estado mínimo de Nozick, aparecen dos tipos de miembros: los que pueden ser denominados «miembros plenos» y los "miembros de segunda clase», incorporados mediante la indemnización del pago de sus pólizas de protección. La cuestión que se plantea es la de saber si ésta es una situación definitiva o tan sólo transitoria. Para que fuera definitiva, habría que aceptar que los miembros de segunda clase pueden convertirse en free riders profesionales: gozarían de las ventajas de la seguridad y de los servicios públicos sin pagar la cuota como miembros plenos. Por supuesto que los miembros de segunda clase tienen interés en seguir siendo free riders; lo que importa es saber si tienen derecho (desde el punto de vista moral, que es el que le importa a Nozick) para ello. Según Nozick, la asociación es la que produce la seguridad y, por lo tanto, de acuerdo con la concepción lockeana de la propiedad (que el propio Nozick acepta), esta seguridad es propiedad de la asociación y ésta tiene un derecho exclusivo a su control. La asociación no ha enajenado esta propiedad (la seguridad) a pesar de que ha garantizado su posesión a los miembros de segunda clase. Por lo tanto, de acuerdo con el principio de cnajenación injusta de Nozick, los miembros de segunda clase perjudicarían a la asociación si no le pagasen el servicio prestado. Como la póliza de miembro pleno es más barata que los beneficios de seguridad que reciben, los miembros de segunda clase optarán, si son racionales, por convertirse en miembros plenos. No hacerlo, sería adoptar una posición de free riders, beneficiándose de la póliza gratis y de la seguridad de que ahora gozan. Si se negaran a hacerlo, el Estado podría obligarlos en virtud del principio de corrección o de rectificación. Este es el razonamiento de Michael Davis quien lo aplica también para el caso de los impuestos, es decir, para la imposición de medidas redistributivas que no cabrían dentro de la concepción de Nozick. Pero, lo que sucede, según Davis, es que el pago de impuestos es el equivalente en dínero de los bienes producidos por el gobierno: «Negarse a pagar impuestos no es quedarse con lo que a uno le pertenece sino retener lo que pertenece a otrom..$^{95}$

La idea de Davis es que la actividad gubernamental, también en la concepción de Nozick, es una actividad productiva (de seguridad, al menos) y es esta naturaleza productiva la que le permite justificar el Estado mínimo e incorporar a toda la población del territorio al Estado ultramínimo. Al caso de la seguridad pueden sumarse otros bienes públicos (tales como vías de comunicación, hospitales, sistemas bancarios, etc.). Estos bienes benefician también a quienes son ricos. En la versión de Nozick, los 
ricos podrían estar dispuestos a correr con los gastos de la producción de bienes públicos sólo como un acto de caridad o supererogatorio. Otro es el enfoque de Davis: el rico no puede aducir que la redistribución es inherentemente injusta ya que se trata de una propiedad que no le pertenece. El rico tiene su posesión como resultado de la actividad productiva del gobierno. Y como la mayoría de los esquemas redistributivos dejan en manos del rico «una parte desproporcionada de la riqueza producida por el gobiemo, no sería racional para él abandonar la asociación aun cuando sea gravado fuertemente por los impuestos. Abandonarla significaría renunciar a todo en lugar de a una parte de lo que deriva de la actividad gubernamentals. ${ }^{96}$ De esta manera, el Estado mínimo de Nozick, en virtud de su propia lógica interna de justificación, tiende a convertirse en un Estado redistribucionista, que era justamente lo que Nozick quería evitar.

¿Qué sucede con cl Estado mínimo y la protección de la autonomía individual manifestada en los derechos de propiedad?

Dejando de lado la cuestión de una posible génesis justa de la propiedad y suponiendo una distribución inicial aceptable de la propiedad, la dinámica del mercado conduce necesariamente a un crecimiento acumulativo de la propiedad y a una notoria injusticia social. Muy pronto se llegará a un umbral en el que se produce el llamado «efecto Mateo», es decir: «Al que tiene se le dará», con la consiguiente acumulación acelerada y desproporcionada de la propiedad. Por más mínima que sea la orientación utilitarista de los ciudadanos, estos no verán pasivamente este proceso si resultan afectados negativamente por el mismo. Por el contrario, tratarán de movilizar el principio de corrección, con la consecuencia de que el Estado se verá obligado a asumir su función de árbitro. Para el caso de interpretaciones opuestas con respecto a la corrección de una transferencia de propiedad, el propio Nozick contempla la necesidad de una decisión estatal y admite la posibilidad de recurrir a criterios de igualdad y de justicia redistributiva. De esta manera, inadvertidamente, el Estado mínimo se desliza hacia un Estado social que, en aras de la paz social o del bienestar general, tendrá que llevar a cabo profundas redistribuciones y que reducir, por lo menos, las desigualdades extremas. Pero, para estas funciones, el Estado de Nozick está muy mal equipado: como posee un monopolio de decisión tan sólo de facto y no de iure, tendrá que requerir la aprobación de los ciudadanos para poder cerrar la laguna de legitimidad que resulta de su existencia (prohibida) como Estado intervencionista. El peligro aquí presente es justamente el de un Estado totalitario si no quiere aceptar la salida del Estado social de derecho, algo que contradiría el propósito de la teoría de Nozick. ${ }^{97}$

Es interesante recordar que uno de los argumentos centrales del neoliberalismo en contra del Estado social del derecho es el de la perversidad de las medidas redistributivas del Estado, en el sentido de que con ellas se logra justamente lo opuesto a lo proclamado. 
Pero, el fenómeno de la perversidad se manifiesta justamente en una de las versiones neoliberales más radicales de la filosofía política contemporánea, como es la de Robert Nozick. Esto arroja serias dudas acerca de la viabilidad del proyecto libertario: si lo que se pretende es asegurar la libertad individual, la guía de la mano invisible a partir de un supuesto estado de naturaleza lockeano nos conduce a un Estado que, sólo si prescinde del consenso fáctico de sus ciudadanos, es decir, viola el principio de un individualismo radical, puede asegurar la paz social. Esta es una consecuencia realmente trágica para un neoliberal.

3.1.1.5. Subjetivismo y legitimidad. Ante el fracaso de todas estas propuestas, podría pensarse que tal vez tengan entonces razón quienes aducen quc la democracia liberal está fundamentalmente basada en el subjetivismo de los valores éticos. Así lo sostienen los partidarios de la llamada corriente crítica del derecho y quienes interpretan la tolerancia -virtud fundamental de todo sistema democrático- como manifestación de este subjetivismo.

Veamos ambas posiciones.

I) Los llamados "Critical Legal Studies» americanos han centrado su crítica en la rule of law liberal.

La tesis central es que la teoría jurídica y política liberal es «incoherente», uinternamente inconsistente», «autocontradictoria». En cualquier sociedad caracterizada por el pluralismo moral, religioso y político, sería imposible conservar la rule of law sin violar el principio liberal clave, es decir, que el Estado debe mantenerse neutral en cuestiones vinculadas con aquello que confiere valor y significado a la vida humana. Si la rule of law liberal es la que se da en condiciones de pluralismo y el Estado se atiene a ella y al principio liberal de la neutralidad, entonces la rule of law es imposible.

Andrew Altman ${ }^{98}$ ha resumido las tesis de los "Critical Legal Studies" en tres argumentos principales. El primero sostiene que no puede haber un proceso neutral para el dictado de las reglas jurídicas en un contexto de pluralismo moral, religioso y político. El segundo afirma que no puede haber un proceso neutral para la interpretación de las reglas jurídicas en un contexto de pluralismo moral, religioso y político. El tercer argumento se refiere a una distinción cuya institucionalización el liberalismo considera esencial para el mantenimiento de la neutralidad del proceso legal: la distinción entre derecho y política.

Según Roberto Unger, existen dos contradicciones en el centro de la teoría jurídica y política liberal y ambas destruyen la posibilidad de la rule of law liberal. La primera de ellas se refiere al proceso mediante el cual las reglas jurídicas son dictadas: nó existe ningún proceso que pueda satisfacer la exigencia de la moral política liberal en el sentido de contar con un 
procedimiento neutral de legislación. La segunda se refiere al procedimiento a través del cual las normas jurídicas son interpretadas: no existe ningún procedimiento que satisfaga el requisito de neutralidad. La primera antinomia puede ser llamada la «antinomia de la legislación»; la segunda, la «antinomia de reglas y valores».

Ambas antinomias estarian enraizadas en el hecho de que en la teoría liberal y en la sociedad liberal, los valores son considerados como subjetivos. Esta subjetividad de los valores traería como consecuencia un problema de orden: si no hay valores objetivos y si el hecho de que existan valores compartidos es un rasgo accidental de toda sociedad, ¿cómo es posible crear un orden estable?, y un problema con la libertad: ¿cómo se justifica el sometimiento de unas personas a las valoraciones subjetivas de otras?

La nule of law, es decir, la solución liberal para asegurar la paz en una sociedad pluralista tiene que tener necesariamente un carácter autoritario para quienes no comparten los valores expresados en aquélla. Dado el carácter subjetivo de la concepción liberal de los valores, ella misma tiene que admitir que no puede haber una solución valorativamente neutra.

Resumiendo, puede decirse que el pluralismo del Estado liberal hace que la regla de derecho sea, a la vez, necesaria e imposible. ${ }^{99}$

Dicho con las palabras de Costas Douzinas:

La rule of law occidental o Rechtsstaat fue concebida como una respuesta a la degeneración del consenso moral. Pero, las condiciones que condujeron a su creación [...] le impidieron proporcionar lo que pretendía: una resolución neutral, no subjetivista de los desacuerdos valorativos y del conflicto social. ${ }^{100}$

El argumento central de los «Critical Legal Studies» en el aspecto que aquí he considerado apunta, como hemos visto, a la imposibilidad de la neutralidad de la rule of law en una sociedad pluralista. Para que esta tesis fuera verdadera, habría que establecer una conexión conceptual entre Estado liberal y relativismo. Creo que esto es falso; a ello habré de referirme en la próxima conferencia.

II) Con respecto al caso de la tolerancia, no he de extenderme en su consideración ya que lo he tratado en otro trabajo. ${ }^{101}$ Baste decir lo siguiente:

Conviene distinguir entre los tolerantes sensatos y los insensatos. Esta calificación depende de las razones que se aduzcan para la tolerancia.

Herbert Marcuse es quizás uno de los autores que con mayor vehemencia y claridad ha intentado mostrar los peligros de una tolerancia insensata y acuñado para ella la expresión de la «tolerancia represiva».

El argumento central de Marcuse es que el sistema justificatorio al que suele recurrirse en la sociedad capitalista ofrece malas razones. Son 
ellas las que permiten extender la tolerancia a «medidas, condiciones y formas de comportamiento políticas que no deberían ser toleradas porque obstaculizan o destruyen las posibilidades de llevar una existencia sin temor y sin miseria». ${ }^{102}$ Se trataria aquí de una tolerancia indiscriminada que conduciría a una aparente homogeneización de la sociedad pero que, en verdad, consolida las desigualdades. Marcuse exigía una "tolerancia diferenciada», con "fundamentación racional" que tuviera en cuenta las buenas razones aducidas por John Stuart Mill: la conexión que existe entre libertad y verdad aplicada a la posibilidad de desarrollo de la autonomía personal. Una tolerancia ilimitada "se vuelve problemática cuando no existe su fundamento racional, cuando la tolerancia es impuesta a individuos manipulados y adiestrados, que repiten las opiniones de sus señores y la heteronomía se convierte en autonomía». ${ }^{103}$

La tolerancia indiscriminada, la tolerancia pura, sin limitaciones, termina negándose a sí misma y en su versión más radical equivaldría a la eliminación de toda regulación del comportamiento humano. Esto es lo que clásicamente se ha llamado "estado de naturaleza» y que encontrará su descripción más aterradora en la versión hobbesiana.

- Pero, también sin llegar al extremo de Hobbes, puede afirmarse que la democracia representativa, en tanto institucionalización de la tolerancia, encuentra sus límites cuando pretende violar las buenas razones que la fundamentan: el respeto a la autonomía individual y la imposición de deberes negativos y positivos de acuerdo con el principio de la mayoria.

La aceptación de estos límites, cuya violación vuelve insensata la tolerancia, parece tener la curiosa consecuencia de que ella estaría enmarcada por un cerco de prohibiciones inviolables cuya lesión sería intolerable. John Stuart Mill, tan celoso defensor de la tolerancia, no estaba dispuesto a aceptarla cuando ella implicaba violar el principio de daño a terceros. El "principio de no dictadura" de Kenneth $J$. Arrow ${ }^{104}$ no resulta muy convincente cuando alguien «dictatorialmente» impone sus preferencias para salvar la vida de personas inocentes, en contra de una decisión mayoritaria. $\mathrm{Si}$ alguien en la tristemente célebre reunión del Lago de Wann en Berlín, en 1942, en la que se adoptó la "solución final de la cuestión judía", hubiera impuesto "dictatorialmente" sus preferencias de respeto a la dignidad humana, consideraríamos que su actitud es moralmente encomiable. A primera vista resultaría pues que quien está dispuesto a asumir una actitud intolerante es, en ciertas circunstancias, una persona que merece el mayor respeto. Dicho con otras palabras, la intolerancia no sólo no sería la negación interna de la tolerancia sino una condición sine qua non de esta última, algo que ya no resulta curioso sino hasta paradójico.

Pero, si se analizan las cosas más de cerca, no cuesta llegar a la conclusión de que conviene introducir algunas matizaciones. Es verdad que un cerco de prohibiciones puede ser cntendido como un cerco de intole- 
rancias en el sentido de que lo prohibido es lo deónticamente imposible y la intolerancia incluye también al acto no tolerado en la categoría de lo deónticamente imposible dentro del respectivo sistema. Pero esto no significa que imponer prohibiciones sea exactamente lo mismo que expresar intolerancias. $\mathrm{La}$ intolerancia tiene una connotación negativa de la que, en principio, carece la prohibición. Lo que molesta en la intolerancia es que ella se basa en malas razones. En este sentido tiene algo en común con la tolerancia insensata. La diferencia consiste en que la intolerancia aduce malas razones para imponer prohibiciones mientras que la tolerancia insensata se apoya en malas razones para aumentar el campo de lo permitido. En algunos casos, como los señalados por Marcuse, el resultado de la tolerancia insensata puede ser una manifiesta injusticia no muy diferente del que provoca la intolerancia, pero ello no tiene por qué ser necesariamente así.

Si la calidad de las razones es la que permite distinguir entre la tolerancia sensata y la insensata por una parte y la intolerancia, por otra, conviene detenerse a analizar cuál puede ser el criterio más adecuado para establecer una línea de demarcación entre ambos tipos de razones. Ello habré de hacerlo en la próxima y última de estas conferencias Aranguren.

\section{Un nuevo punto de partida}

En las dos primeras conferencias, intenté demostrar que la democracia y el mercado, librados a sí mismos, tienen una tendencia a autodestruirse, frustrando así la obtención de los objetivos para los que fueron concebidos. Esta propiedad disposicional de la democracia y del mercado es lo que permite calificar de suicidas a ambas instituciones.

En la tercera conferencia, pasé revista a diversas soluciones propuestas con respecto al problema del control de la democracia representativa, concentrándome especialmente en los aspectos vinculados con las limitaciones del soberano. Llegué a la conclusión de que las limitaciones del llamado soberano 1 son de tipo jurídico y le están impuestas por el soberano 0 . De esta manera procuré solucionar el problema lógico de la autolimitación. Con esto no quedaban, por cierto, totalmente superadas las dificultades, ya que era necesario buscar criterios de limitación ética del soberano 0. Esta problemática está estrechamente vinculada con la de la legitimidad del soberano 0 , es decir, con la legitimidad del sistema político que crea. Ello me llevó a analizar diversas propuestas que pueden ser subsumidas bajo el título general de criterios de legitimidad. Como ninguna de ellas me pareció satisfactoria, pesa ahora sobre mí la tarea de sugerir una nueva vía que permita dar respuesta a las tendencias suicidas de la democracia representativa vinculadas con el comportamiento parasitario por parte de los representantes, frenar la disposición autodestructora del mer- 
cado, y formular una versión de la tolerancia que supere las objeciones subjetivistas y la concepción relativista de la democracia liberal.

Para ello, habré de dar los siguientes pasos:

4.1. Presentaré una definición de legitimidad de los sistemas políticos que esté libre de las objeciones expuestas en la conferencia anterior.

4.2. Indicaré cuáles son, en mi opinión, los posibles recursos para evitar los peligros del suicidio parlamentario.

4.3. Indicaré algunos medios de control de la actividad mercantil.

4.4. Sugeriré una aproximación a una concepción de las buenas razones de la tolerancia.

\subsection{El concepto de legitimidad}

En la conferencia anterior subrayé los inconvenientes que trae aparejada la aceptación del consenso fáctico como fundamento de la legitimidad. Pero, de aquí no se infiere que el consenso fáctico de ciudadanos autónomos sea un dato irrelevante para la vigencia efectiva de un sistema político legítimo.

Por lo pronto, el consenso fáctico -unánime o ampliamente mayoritario- de los miembros de un sistema político es un elemento fundamental de estabilidad. Si el sistema posee legitimidad, su aprobación por parte de los ciudadanos es relevante en grado sumo para el afianzamiento de una sociedad justa. Pero no sólo esto. Un sistema que pretenda poseer legitimidad tiene que tratar a sus ciudadanos, por lo general, como seres autónomos y sólo excepcional y transitoriamente puede aplicar medidas paternalistas como las de Filógeno $I$.

El deber moral de tratar como regla general a todos los ciudadanos como seres autonomos, capaces de formular sus planes de vida sobre la base de sus propias reflexiones, resulta de la combinación de dos premisas, una empírica y otra normativa. La primera nos dice que todos los seres humanos son básicamente iguales por lo que respecta a la posibilidad de hacer uso de la razón. La segunda, impone el deber de adoptar una actitud imparcial desde la que puedan formularse reglas universalizables del comportamiento humano.

No es necesario invocar a Descartes para aceptar la evidencia biológica de la premisa empírica. Ha sido siempre tomada en cuenta, aun por quienes han intentado justificar y otorgar legitimidad a sistemas políticos aberrantes. La estrategia de justificación no consistía en negar la igualdad esencial de los seres humanos sino justamente en afirmarla, excluyendo de la clase de los seres humanos a grupos de la población de un país a a poblaciones enteras. Tal es el caso de la tesis sustentada por Juan Ginés de Sepúlveda: 
Y siendo esto así, bien puedes comprender [...] si es que conoces las costumbres y la naturaleza de una y otras gentes, que con perfecto derecho los españoles imperan sobre estos bárbaros del Nuevo Mundo e islas adyacentes, los cuales en prudencia, ingenio, virtud y humanidad son tan inferiores a los españoles como los niños a los adultos y las mujeres a los varones, habiendo entre ellos tanta diferencia como la que va de gentes fieras y crueles a gentes clementísimas, de los prodigiosamente intemperantes a los continentes y templados, y estoy por decir que de monos a hombres. ${ }^{105}$

En el siglo $\mathrm{Xx}$, la barbarie nazi recurrió al concepto de Unmensch (no humano) para justificar la «solución final» del "problema» de los judios europeos.

Pero, así como es verdad que las personas son esencialmente iguales en tanto seres individuales dotados de razón, también lo es que existen entre ellas diferencias accidentales, algunas de las cuales son superables y otras, irremediables. No tener en cuenta estos datos de la realidad significaría imponer una discriminación injustificable, es decir, constituiría una violación del principio de igualdad. Este último requiere en estos casos dos tipos de medidas: superación y compensación, según se trate de diferencias accidentales superables o no.

Dentro de la primera categoría figuran aquellas desigualdades a las que James M. Buchanan ha llamado «ambientales», es decir, aquellas que están vinculadas con la disponibilidad o la carencia de recursos económicos, culturales o políticos. Su no superación debe estar justificada y, si se admite la vigencia básica del principio de igualdad, las desigualdades estarán justificadas si y sólo si contribuyen a reducir las desigualdades accidentales superables. La no justificabilidad de las desigualdades accidentales en la sociedad capitalista constituye, como es sabido, uno de los temas centrales de los estudios de Jürgen Habermas sobre la legitimidad.

En el caso de las desigualdades no superables, lo que requiere el principio de igualdad es la compensación de aquellas que constituyen un déficit de igualdad o, si se quiere, una incapacidad básica para la adopción y/o realización de planes de vida. Estas medidas pueden ser incluidas en la categoría de las disposiciones paternalistas éticamente justificables. En este sentido, el paternalismo, lejos de ser "agresivo", como piensa Robert Nozick, es un instrumento adecuado para salvaguardar la autonomía de las personas y reestablecer la igualdad.

Si se acepta el principio de igualdad y las consecuencias que de al se infieren, puede proponerse la siguiente definición de legitimidad:

D1:

Un sistema politica $S^{*}$ posee legitimidad si y sólo si respeta el principio de la igualdad esencial de todos sus miembros y procura superar y/o compensar las desigualdades accidentales de los mismos.

El procedimiento más adecuado para lograr este objetivo es el demo- 
crático pluralista, que permite el mayor grado de participación, es decir, la vigencia del principio de igualdad en el ámbito político.

Las normas o decisiones que se obtengan a través del procedimiento democrático deben a) asegurar que no se lesione el principio de igualdad esencial y $b$ ) promover la superación y/o compensación de las desigualdades accidentales. Dicho con otras palabras: asegurar el cumplimiento de los deberes negativos y de los deberes positivos que, en tanto tales, imponen ciertamente limitaciones al ejercicio de la autonomía individual.

Como es sabido, el neoliberalismo se opone básicamente a la existencia de deberes positivos aduciendo su asimetría con los deberes negativos basada en el doble argumento de la distinción entre acciones y omisiones y en los costos del cumplimiento de los deberes positivos. Creo que ambos argumentos son falsos.

Los deberes que impone la ética - sean negativos o positivos- no constituyen un fin en sí mismos sino que tienen un carácter eminenternente instrumental. La ética no es un lujo o un ejercicio más o menos ingenioso de los filosofos sino un conjunto de principios y reglas con fines pragmáticos.

Con respecto a los deberes positivos generales, deseo proponer la siguiente definición:

Deberes positivos generales son aquellos cuyo contenido es una acción de asistencia al projimo que requiere un sacrificio trivial y cuya existencia no depende de la identidad del obligado ni de la del (o de los) destinatario(s) y tampoco es el resultado de algún tipo de relación contractual previa.

La existencia de deberes negativos generales es una de las características del llamado "estado de naturaleza» en su versión lockeana, cuya superación es el punto de partida de la justificación del Estado liberal. El objetivo de esta superación era la eliminación de la inseguridad social provocada principalmente por la vulnerabilidad humana, el altruismo limitado, la igualdad aproximada, la comprensión y fuerza de voluntad limitadas y la escasez de recursos. ${ }^{106}$ La propuesta de solución fue la institucionalización de deberes positivos especiales reducidos a las funciones de la policía y del juez. Hasta qué punto esta vía fue insuficiente lo demuestra la historia de las crisis del Estado liberal en su versión restringida de conjunción de deberes negativos generales y deberes positivos especiales. La necesidad de ampliar el campo de los deberes positivos dio origen al Estado social de derecho.

Pero, así como en el plano de la moral individual la creación del Estado lockeano no eximía de la obligación de cumplir los deberes negativos generales, tampoco el establecimiento del Estado social exime de la obligación de cumplir con los deberes positivos generales, cuya justificación es la misma que la de los deberes negativos generales: la protección de bienes que se consideran valiosos. La clase de estos bienes está definida por crite- 
rios de coherencia y de equidad; es decir, no es posible excluir de ella arbitrariamente bienes que poseen las características definitorias para ser sus miembros.

En la tradición del liberalismo europeo, la vía de la imposición de deberes sociales comenzó con el reconocimiento de la necesidad de proteger al físicamente más débil y ahorrar los costos de la autodefensa. Que la debilidad de los integrantes de un grupo social puede ser no sólo física es cosa harto sabida, y que existen sociedades en las cuales la insatisfacción de necesidades vitales es tan grande que ni siquiera tiene sentido comenzar a hablar de justicia, también. La misma idea de protección al "débil» y su equiparación al afuerte" exige, por ello, un refuerzo de los deberes positivos de asistencia. Ello aumenta, por cierto, la clase de las omisiones moralmente reprochables pero no nos lleva a lo que ha sido llamado el «dilema de Fishkin" ni nos hace responsables por todos los males que ocurren en el mundo. El reconocimiento de deberes positivos generales no significa tampoco la autodestrucción de los obligados ni es la etapa previa al «trágico eventos de la pauperización que preveía T.R. Malthus.

Si se acepta que los deberes negativos son impuestos para la protección de bienes necesarios para la realización de cualquier plan de vida y se está de acuerdo en que se puede dañar por omisión, es también obvio que las razones que valen para la implantación de los deberes negativos valen también para los positivos. Esto es lo que Leibniz llamaba el principio de equidad, es decir, de identidad o de igualdad de razones. La negación de este principio conduce a una fatal contradicción. Quien coherentemente desee negar la justificabilidad de los derechos positivos generales no puede limitarse a negar el Estado social de derecho; tiene que ir más lejos y afirmar como Benjamin Hart y Charles Murray: "Al igual que la izquierda de los años sesenta, nosotros exigimos: ¡destruid el Estado!n, Si, en cambio, desea proteger la autonomía individual y los bienes primarios que permiten su desenvolvimiento - como lo desea el propio Nozick - no puede darse por satisfecho con la mera imposición de los deberes negativos.

Por ello es que la distinción entre libertad negativa y libertad positiva, en la que suelen insistir los neoliberales, es falsa. Equiparar la protección de la salud a la conservación de monumentos - tal como lo hace Tibor $\mathbf{R}$. Machan a quien me referí en la segunda conferencia- es una aseveración no sólo moralmente inaceptable sino falsa por violar un principio elemental de coherencia. En el campo de la moral, la violación del principio lcibniziano de coherencia conduce a la implantación de lo que cabalmente pueden ser llamadas «situaciones indecentes".

Si eso es así, la coherencia liberal exige la aceptación de un Estado no sólo protector sino productor de bienes públicos y redistribuidor de cargas y beneficios. Es esto lo que pensaba tambiên Emile Durkheim cuando afirmaba: "Plus l'État est fort, plus l'individu est respecté». La alternativa 
al Estado total no es el Estado mínimo de Robert Nozick, de la misma manera que la alternativa al absolutismo ético no es el relativismo.

La definición de legitimidad reza ahora:

D2:

Un sistema politico $S^{*}$ posee legitimidad si y sólo si respeta el principio de la igualdad esencial de todos sus miembros y procura superar y/o compensar las desigualdades accidentales a través de la imposición de deberes negativos y positivos sancionados mediante un procedimiento democrático pluralista.

Es obvio que la importancia de las diferencias accidentales entre los miembros de una comunidad política son relativas a los recursos económicos y culturales de la misma. La percepción de estas desigualdades varía según los tiempos y las sociedades. En este sentido, la legitimidad es también relativa a un determinado contexto histórico-espacial. Ello explica por qué, a medida que se expande el círculo de la ética (para utilizar la conocida expresión de Peter Singer) y/o aumenta la disponibilidad de recursos (económicos, técnicos o culturales), aumenta también la clase de las desigualdades accidentales que deben ser superadas para que el sistema conserve su legitimidad. Si esto es así, puede decirse:

\section{D3:}

Un sistema político $S^{*}$ posee legitimidad si y sólo si respeta el principio de la igualdad esencial de todos sus miembros y procura superar y/o compensar las desigualdades accidentales a través de la imposición de deberes negativos y positivos sancionados mediante un procedimiento democrático pluralista, de acuerdo con la disponibilidad de recursos de la respectiva sociedad.

En estas propuestas de definición de la legitimidad se hace referencia al procedimiento democrático pluralista y al principio de igualdad. Conviene formular algunas precisiones al respecto. La igualdad a la que me refiero no sólo recoge la idea de la igualdad de autonomía sino también la igualdad en el sentido de que puede exigirse de todo ser humano la capacidad de distanciarse de sus propios intereses y comprender que ellos deben tener la misma relevancia cuando se trata de la formulación de normas morales. Se trata, pues, de una igualdad entendida tanto en sentido fáctico como normativo. Este último aspecto puede ser reformulado con el concepto de universabilidad. Por cierto que alguien podría preguntar ¿por qué ha de aceptarse la universabilidad de las normas morales? La respuesta que considero más obvia es la siguiente: la actividad de la formulación de normas éticas, es decir, normas que ofrecen la posibilidad última de justificación de la conducta humana, está sujeta a ciertas restricciones que son las que justamente le permiten cumplir la función que de ella se espera. Por ello no es posible equiparar sin más consenso racional (tampoco en el sentido reforzado de David Gauthier) y corrección ética. No toda razón es una buena razón desde el punto de vista ético. Para que sea tal ha de 
satisfacer el requisito de poder ser aceptada por todo aquel que esté dispuesto al ejercicio de su razón bajo condiciones de imparcialidad. Al respecto no existe disenso entre quienes se ocupan de cuestiones vinculadas con fundamentaciones éticas. Se puede, en este sentido, pensar en la formulación kantiana del imperativo categórico o, si se quiere buscar una fundamentación de raíz empírica, recordar a Hume:

La noción de la moral implica algún sentimiento común a toda la humanidad, que recomienda el mismo objeto a la aprobación general y hace que todo hombre, o la mayoria de los hombres, coincidan en la misma opinión o decisión al respecto. Implica también algún sentimiento tan amplio como para poder ser extendido a toda la humanidad y hacer que las acciones y la conducta, hasta de las personas más remotas, sean objeto de aplauso o de censura, según que coincidan o no con la regla acerca de lo que es correcto que se ha establecido. ${ }^{107}$

$\mathrm{Y}$ a quien siguiera aduciendo que el principio de universabilidad de las normas éticas no le convence podría respondérsele que su argumento es similar al de quien sostiene que no le convence la exigencia de falsabilidad que rige para las leyes de la ciencia empírica.

\subsection{Contral del comportamiento parasitario}

En la primera conferencia, al señalar las tendencias suicidas de la democracia representativa derivadas de comportamientos parasitarios, me detuve especialmente en los peligros de la "obesidad parlamentaria», del "despotismo elegido" y de la "agenda impuesta».

Justamente el criterio de la universabilidad de los principios éticos es relevante también con respecto a las limitaciones de la democracia representativa y pluralista y a las propuestas de freno a las tendencias suicidas. Quienes como Buchanan insisten en la importancia del consenso lo hacen porque temen -con no poca razón-que las decisiones mayoritarias puedan poner en peligro el respeto a la autonomía individual de las personas.

Por ello, el consenso parlamentario tiene que estar encuadrado dentro de las siguientes condiciones:

I) La existencia de una sociedad homogénea.

La idea de la necesidad de una sociedad homogénea como presupuesto de la democracia representativa no es nueva: ha sido sostenida, desde distintas perspectivas, por Edmund Burke y también por Carl Schmitt. No es este el momento de analizar estas posiciones. Aquí tan sólo me limitaré a proponer una definición de sociedad homogénea:

Una sociedad es homogénea si y sólo si sus miembros tienen la posibilidad de ejercer los derechos vinculados con la satisfacción de sus necesidades básicas.

Hermann Heller, celoso defensor de la República de Weimar, conside- 
raba igualmente que la homogeneidad social era condición necesaria para el funcionamiento de la democracia representativa. Así, al final de los años veinte, escribió:

Sólo cuando el proletariado crea que la igualdad democrática de derechos de su adversario poderoso condena al fracaso la lucha de clases bajo formas democráticas, sólo en ese momento se impondrá la dictadura. ${ }^{108}$

La falta de confianza del proletariado en las reglas del juego democrático era, según Heller, el resultado de la desigualdad social, que convertía el summum ius en summa iniuria.

Treinta años más tarde, José Luis Aranguren afirmaba:

Los individuos o grupos aislados, los que se sienten excluidos, a la izquicrda o a la derecha, social o regionalmente, de la politica, los que se consideran desprovistos de derechos, atención pública o status, asi como los grupos sociales en declive o mal dotados para una adaptación a las demandas de una civilización en transición o expansión, y quienes se consideran sin oportunidades, condenados a la inmovilidad, a un imposible ascenso social, se inclinan, normalmente, al disconformismo radical y, por lo tanto, a la repulsa de una democracia que, para ellos, no es tal.109

La exigencia de homogeneidad social, tal como aquí la he entendido, pienso que evita este peligro.

II) La exclusión de ciertos asuntos de la decisión parlamentaria.

Sea que uno sostenga como Edmund Burke que la discusión parlamentaria es el medio adecuado para alcanzar la verdad política o que, siguiendo a Hans Kelsen, se afirme que la negociación y el compromiso constituyen la mejor aproximación posible al ideal de la libertad y la igualdad, podría pensarse a primera vista que, en principio, no existen cuestiones que puedan ser excluidas del debate parlamentario.

Sin embargo, ni Burke ni Kelsen sostienen esta apertura irrestricta. En Burke, el límite está trazado por el presupuesto de la defensa de la propiedad burguesa. Además, según él, sólo podian adoptarse aquellas medidas que eran "verdaderas", es decir, que satisfacían los intereses de la totalidad. Kelsen señaló la necesidad de distinguir entre el "principio de la mayoría" y el "dominio de la mayoría». ${ }^{10}$ Aquél exige el respeto a la autonomía de la minoría como un derecho que no puede ser objeto de negociación parlamentaria. Este derecho constituye el núcleo del sistema parlamentario. Es lo que, apropiándome del título de una conocida obra de la literatura española actual, he llamado «coto vedado» de lo no negociable.

Este "coto vedado" está integrado por aquellos derechos derivados del principio de igualdad básica y de la exigencia de superación y/o compensación de las desigualdades accidentales. El respeto de este "coto vedado", es decir, la accesibilidad al goce de los derechos en él incluidos es lo que 
confiere homogeneidad básica a la sociedad, a la vez que impone limitaciones a las decisiones gubernamentales, siendo aquí irrelevante el que aquéllas cuenten con el consentimiento o no de los gobernados. Homogeneidad en este sentido no significa nivelación de la posibilidad de satisfacción de todo tipo de deseos e intereses sino tan sólo de aquellos que podrían ser llamados "primarios» $\mathrm{y}$, en tanto tales, están caracterizados por su universabilidad.

Otra es, en cambio, la situación con respecto a la validez ética de las reglas que regulan la satisfacción de los deseos e intereses secundarios (o particulares, si se quiere utilizar la designación habermasiana) de los miembros de la sociedad. Esta validez sí depende de la aceptación fáctica de sus destinatarios. Para este ámbito valen las consideraciones de Fishkin sobre la cultura política autorreflexiva.

Con respecto a la validez de los derechos dentro del «coto vedado» de los bienes básicos, la voluntad y los deseos de los miembros de una sociedad son irrelevantes. En este ámbito, está plenamente justificada una actitud paternalista en caso de que los miembros de la comunidad no comprendan la importancia de estos bienes básicos. Esto es así porque una clara señal de irracionalidad o de desconocimiento de relaciones causales básicas - como la que existe entre la disponibilidad de tales bienes y la realizabilidad del respectivo plan de vida- es el hecho de la no aceptación del otorgamiento de los bienes básicos. En ambos casos -irracionalidad o ignorancia- quien no comprende la importancia de los bienes básicos debe ser calificado de incompetente básico. Así lo pensó Filógeno I.

El peligro de no respetar el coto vedado lo veía claramente Abraham Lincoln cuando decía:

Si en virtud de la mera fuerza de los números, una mayorfa puede privar a una minoria de un derecho constitucional escrito, ello puede justificar, desde el punto de vista moral, la revolución.

La imposición del coto vedado de lo no negociable puede constituir un buen freno para la "obesidad parlamentaria».

III) La vigencia plena del principio de publicidad.

Una vez más conviene recordar reflexiones de Kelsen:

Como la democracia tiende fundamentalmente a la seguridad jurídica y, por lo tanto, la legalidad y la previsibilidad de las funciones estatales, existe en ella una poderosa inclinación a crear organizaciones de control, que sirvan de garantía a la legalidad. De estas garantías, la más firme es el principio de publicidad. La tendencia a la claridad es especificamente democrática y cuando se afirma a la ligera que en la democracia son más frecuentes que en la autocracia ciertos inconvenientes políticos, especialmente las inmoralidades y corrupciones, se emite un juicio demasiado superficial o malévolo de esta forma política, ya que dichos inconvenientes se 
dan lo mismo en la autocracia, con la sola diferencia de que pasan inadvertidos por imperar en ella el principio opuesto a la publicidad. En lugar de claridad, impera en la autocracia la tendencia a ocultar: ausencia de medidas de control -que no servirian más que para poner frenos a la acción del Estado-, y nada de publicidad, sino el empeño de mantener el temor y robustecer la disciplina de los funcionarios y la obediencia de los súbditos, en interés de la autoridad del Estado."

No puede sorprender, por ello, que en casi todas las Constituciones modemas de los Estados democráticos se incluyan disposiciones que hacen referencia expresa a la publicidad del proceso jurídico-político.

En su ya clásico libro sobre derecho constitucional alemán, Konrad Hesse afirma:

En estas formas de la participación y conformación decisivas por parte del pueblo, la democracia vive de la publicidad del proceso político. Las elecciones y votaciones pueden cumplir la función que les corresponde sólo si el ciudadano está en condiciones de formarse un juicio sobre las cuestiones que hay que decidir [...] y si con respecto al desempeño de las funciones por parte de los dirigentes políticos sabe lo suficiente como para poder prestarles su aprobación o rechazarlos. La opinión pública presupone el conocimiento de las cuestiones públicas. ${ }^{112}$

La contrapartida necesaria de la libertad de expresar la opinión es la libertad de información como fundamento de la formación de la opinión democrática [...] sólo el ciudadano informado está en condiciones de formarse un juicio propio y de colaborar en el proceso democrático en la forma intencionada por la Ley Fundamental. ${ }^{113}$

En el apéndice II a La paz perpetua, Kant subraya el carácter trascendental de la publicidad: sin ella "no habría justicia (que sólo puede ser pensada como públicamente manifiesta) ni habría tampoco derecho, que sólo se otorga desde la justicia».

Y más concretamente:

Después de prescindir de todo lo empírico que contiene el concepto de derecho político y de gentes [...] se puede denominar fórmula trascendental del derecho público a la siguiente proposición:

"Son injustas todas las acciones que se refieren al derecho de otras personas cuyos principios no soportan ser publicados."

No hay que considerar a este principio como un mero principio ético (perteneciente a la doctrina de la virtud) sino que hay que considerarlo también como un principio jurídico (que afecta al derecho de los hombres). Un principio que no pueda manifestarse en alta voz sin que se arruine al mismo tiempo mi propio propósito, un principio que, por lo tanto, debería permanecer secreto para poder prosperar y al que no puedo confesar públicamente sin provocar indefectiblemente 
la oposición de todos, un principio semejante solo puede obtener esta universal y necesaria reacción de todos contra mí, cognoscible a priori, por la injusticia con que amenaza a todos., ${ }^{114}$

No está de más subrayar que aquí Kant habla de la autodestrucción, del «arruinarse a sí mismo» de los principios que no pueden ser prodamados públicamente. Es la idea del suicidio en la que he insistido en estas conferencias. También en neokantianos como John Rawls, los principios de la justicia tienen que satisfacer la condición de publicidad, pues, cada cual tiene que estar en condiciones de justificar estos principios frente a los demás y ello no sería posible si su publicación fuera "autodestructiva" 0 , como decía Kant, si su manifestación «en alta voz» arruinase mi propio propósito:

La publicidad puede ser explicada como aquello que asegura que el proceso de justificación puede llevarse perfectamente a cabo [...] sin efectos adversos. Pues la publicidad permite que todos puedan justificar su conducta ante cada cual (cuando su conducta es justificable) sin autofrustración u otras consecuencias perturbadoras. Si tomamos seriamente la idea de una union social y de la sociedad como una unión social de tales uniones, entonces la publicidad es ciertamente una condición natural."15

En cuanto principio, el de publicidad es una norma que exige un grado máximo de realización, de acuerdo con las posibilidades jurídicas y fácticas existentes. Utilizando la terminología propuesta por Robert Alexy, ${ }^{116}$ puede decirse que el principio de publicidad es un "mandato de optimalidad" caracterizado por el hecho de que puede ser satisfecho en grado diferente según las circunstancias fácticas y las limitaciones jurídicas existentes.

En el caso de la representación parlamentaria, la publicidad de las discusiones y la exposición de los motivos que condicionan la aprobación de las leyes juegan un papel decisivo para el ejercicio del poder de control por parte de la oposición y del pueblo en general.

La «accesibilidad" del procedimiento legislativo y judicial es un elemento fundamental de la justificación de las decisiones si es que se acepta (como creo que es correcto) que toda justificación es un comportamiento dialógico.

Justamente porque la publicidad es un principio normativo puede servir como criterio para juzgar acerca de la calidad democrática de un sistema político: cuando está presente se habla de razón de derecho, cuando está ausente, de razón de Estado.

La vigencia plena del principio de publicidad puede constituir un buen freno para evitar el peligro del «despotismo elegido».

Iv) El respeto de los intereses objetivos de los ciudadanos.

En las discusiones acerca del ejercicio del poder, desde Edmund Burke hasta Steven Lukes, suele insistirse en la necesidad de distinguir entre los intereses y los deseos de la gente. Esta distinción es la que subyaco a la 
argumentación en favor de la idea del mandato libre de los representantes. La distinción entre intereses y deseos permite superar también el peligro de los esclavos voluntarios y/o felices. La agenda impuesta deja de estar éticamente justificada cuando ella no respeta lo que Lukes llama wintereses objetivos». Una vez más, la aceptación de la idea de la objetividad de los intereses de la gente no habrá de ser admitida por quienes consideren que ello conduce a concepciones absolutistas de la ética.

Pienso que la alternativa absolutismo-relativismo es falsa. La consideración del respeto de los intereses objetivos de las personas, partiendo del reconocimiento de sus necesidades básicas y de los deseos legítimos de las personas, tiene, frente a las teorías del consenso, la ventaja de que evita los llamados "problemas jurisdiccionales" (a los que me referí en la conferencia anterior) del consenso hipotético y las aberraciones a las que puede conducir el consenso fáctico, cuando es también aplicado al ámbito de lo que he llamado "coto vedado». Es justamente el reconocimiento de la existencia de necesidades básicas (en el doble significado de primarias y secundarias) lo que permite, por una parte, obtener el grado de objetividad y universalidad al que aspiran las teorías del consenso y, por otra, imponer la carga de la prueba a quien desee establecer una excepción en el tratamiento básicamente igualitario de las personas. Que esta vía sea la más conveniente, no significa, desde luego, que todos los problemas queden resueltos y que este enfoque pretenda dar la única solución válida para todos los casos concretos que puedan presentarse. Sustentar esta exigencia significaría propiciar una ética absolutista o rigorista, que iría mucho más allá de la objetividad universal.

Las cuatro condiciones que he mencionado constituyen el marco de lo que puede ser llamado el «juego constitucional democráticon. Ellas imponen restricciones no solamente formales sino también materiales. Por supuesto que aquí se plantea el problema del control de su observancia. El establecimiento en las constituciones modernas de tribunales constitucionales encargados de supervisar la actividad del poder legislativo es un buen recurso al respecto. Pero, por supuesto que aquí vuelve a surgir el problema que ya veía John Austin, es decir, quid custodiet ipsos custodes. La única salida a este dilema es volver a recurrir a la idea de un soberano 0 , es decir, el pueblo, que adopte un punto de vista interno democrático.

Si este punto de vista falta, la democracia no corre ya riesgo de suicidio sino que simplemente no existe puesto que este punto de vista es condición necesaria de su existencia.

\subsection{Control de la actividad mercantil}

¿Qué sucede ahora con el caso del mercado?

El ámbito de las transacciones en el mercado presenta una cierta semejanza estructural con el de la negociación y el del compromiso parla- 
mentarios; por ello, lo asechan peligros similares. Esto es lo que me permitió calificar también de institución suịcida al mercado.

Los problemas con los que se ve enfrentado el mercado fueron presentados en la segunda de las conferencias. Muchos de ellos eran tan graves que podría pensarse que, en realidad, no existen buenos argumentos para defender la institución del mercado y que lo más conveniente sería abandonar todo intento de justificación. Esta sería, por cierto, una conclusión falsa. La vía para superar las deficiencias del mercado pasa por el abandono de los intentos de justificación deontológicos. No es que el mercado sea algo bueno en sí mismo sino que su valor depende de los bienes primarios que permite alcanzar o garantizar. Como toda institución social, su mérito o demérito depende de relaciones causales. El valor del mercado es un valor instrumental. Ello nos remite a las justificaciones pragmáticas consideradas en la primera conferencia. Pero, dadas las objeciones formuladas contra ellas, la cuestión debe ser enfocada como un asunto de grado y no de todo o nada.

Tanto la democracia parlamentaria como el mercado tienen valor instrumental. El haber insistido en versiones deontológicas puede explicar el escepticismo de algunos teóricos del derecho público y de la economía con respecto a las relaciones entre democracia y economía, por una parte, y la ética, por otra, sobre todo en la década de los treinta. Los nombres de Lionel Robbins con su libro Essay on the Nature and Significance of Economic Science (1935) y de Hans Kelsen, con su Reine Rechtslehre (1934) pueden ilustrar esta posición.

Según Robbins, cierta clase de juicios de valor, especialmente los de naturaleza ética, debían ser desterrados del campo de la economía. Las comparaciones interpersonales de utilidad, que habian sido consideradas como fundamentales por los teóricos de la economía de bienestar de orientación utilitarista, fueron calificadas por Robbins como "normativas" o «éticas» $y$, por lo tanto, como «no científicas».

En su versión débil, la tesis de Robbins afirmaba que, si se quería hablar de una economía normativa, lo único que podía aceptarse era la formulación de reglas para el uso de recursos escasos, dentro del marco de un mercado perfectamente libre, con miras a la obtención de fines dados de antemano. La justificación de estas reglas sería, pues, hipotética: valdría sólo en relación con ciertos fines u objetivos y sólo para aquellos individuos que los aceptan o comparten. La justificación de los fines, en cambio, superaría los límites de la razón y al respecto lo más sensato sería guardar silencio. En su versión débil, la tesis de Robbins adoptaba una posición ética no cognoscitivista.

En el campo de la filosofía del derecho, Hans Kelsen con argumentos similares a los de Robbins abogaba por una separación radical entre derecho y ética. Justamente una de las delimitaciones que, según Kelsen, de- 
ben asegurar la "pureza" del derecho es la de la separación entre derecho y moral. Al igual que Robbins, Kelsen admitía la posibilidad de una justificación hipotética de los valores y había dado un ejemplo de ello en sus estudios sobre justificación de la democracia publicados en la década de los veinte.

Si se acepta, como creo que es correcto, que el mercado es el ámbito del consenso éticamente aceptable, es obvio que no todo puede ser objeto de la negociación mercantil. También un autor tan afecto al mecanismo del mercado como John Stuart Mill, excluía la posibilidad de ilevar a él la libertad individual y la celebración de contratos de esclavitud. El respeto a los deseos de las gentes no es siempre la mejor vía para asegurarles su bienestar. Dicho con palabras de Brian Barry:

Aunque, en general, la gente puede estar mejor ella misma (es decir, lograr resultados más preferidos) si es legalmente libre para desplegar sus derechos de la manera que ella quiera, hay algunos casos en donde ella puede lograr un resultado que prcfiera más aún si sus derechos están restringidos de forma tal que se le impida renunciar a sus derechos o intercambiarlos en determinados términos. ${ }^{17}$

Esta restricción es justamente la que establece la idea del coto vedado, que vale también para el caso del mercado. Se trata de la exclusión de bienes no susceptibles de ser sometidos a las reglas de la oferta y la demanda. Si todo pudiera ser llevado al mercado, dadas las desigualdades accidentales de las personas, el resultado inevitable sería que algunas de ellas quedarian al final sin bienes para participar en el juego mercantil. La única forma para contener el dinamismo expelente del mercado es fijar un límite de lo legitimamente mercantilizable.

Es verdad que el mercado es el ámbito de la negociación y el compromiso pero es obvio que, en tanto tal, sólo vale para lo que es negociable y acordable. Y lo negociable y acordable no puede ser decidido en el mercado mismo sino que requiere la aceptación de un sistema normativo superior. Este es el de la justicia como virtud social. Sólo desde él pueden formularse los arreglos institucionales que confieren calidad moral al instrumento del mercado. Quien pretenda invertir el razonamiento e inferir valores morales de la actividad incontrolada del mercado habrá de perder su cabeza bajo la guillotina de Hume.

Felix Oppenheim sostiene que las relaciones del mercado pueden ser interpretadas como relaciones de poder recíprocas en las que el comprador y el vendedor intercambian la realización de sus preferencias. Pienso que esto vale sólo para relaciones idealizadas de mercado. En el mercado real lo que se da son más bien relaciones asimétricas y éstas tienden a la violación de la equidad y a aumentar la vulnerabilidad del débil.

Ello requiere el establecimiento de lo que podría llamarse «circunstan- 
cias del mercado", es decir, de arreglos sociales fijados autoritativamente por los poderes democráticamente legitimados del Estado.

Amartya Sen ha señalado con razón que la

[...] especificación del mecanismo del mercado es una especificación esencialmente incompleta de un arreglo social. Aun en el mecanismo de mercado más puro, perfectamente competitivo, no estamos en condiciones de entender exactamente lo que sucederá hasta que no sepamos algo más acerca del resto de los arreglos sociales, en particular la distribución de dotaciones y de la propiedad de los recursos. ${ }^{1: 8}$

Por ello, la sociedad debe también tener un cierto grado de homogeneidad que permita el acceso al mercado de todos los integrantes de una sociedad. Esto es lo que puede ser llamado igualdad de oportunidades de negociación para la adquisición de los bienes primarios necesarios para todo plan de vida.

La aceptación de este enfoque puede permitir evitar caer en la falacia de establecer alternativas absolutas: por un lado el mercado incontrolado y, por el otro, el autoritarismo rampante. Esta posición maniquea parece estar presente en algunas afirmaciones, por ejemplo, de Hayek cuando contrapone la dirección de "todas nuestras actividades por un único plan" a los "esfuerzos espontáneos e incontrolados de todos los individuos", a «las fuerzas espontäneas que se encuentran en una sociedad libre», al "mecanismo impersonal y anónimo del mercado». ${ }^{119}$

Si se acepta el valor instrumental del mercado y las restricciones impuestas por lo que he llamado sus circunstancias, puede quizás lograrse que cumpla las funciones que teóricamente se le han atribuido.

\subsection{Las buenas razones de la tolerancia}

$\mathrm{Si}$ - como dije en la conferencia anterior- la calidad de las razones es la que permite distinguir entre la tolerancia sensata y la insensata por una parte y la intolerancia, por otra, conviene detenerse a analizar cuál puede ser el criterio más adecuado para establecer una línea de demarcación entre ambos tipos de razones.

Es obvio que como la decisión de tolerancia o de intolerancia afecta el comportamiento de terceros, las razones justificatorias que se aduzcan no pueden ser de una índole tal que los valores en los que se apoyan sólo sirvan, en el mejor de los casos, como guía de la propia vida pero no como pautas para la vida social. Estas áltimas presuponen un mínimo de objetividad, es decir, la aceptación de criterios racionales para su defensa o condena. No basta la apelación a mi propia creencia en que $p$ es verdadero para que $p$ pueda ser aceptado como razón justificatoria: «La razón es que a menos que haya alguna forma de aplicar desde un punto de vista imper- 
sonal la distinción entre mi creencia en que algo es verdadero y el que lo sea, una apelación a su verdad es equivalente a una apelación a mi creencia en su verdad».120 John Locke pensaba, con razón, que la determinación del derrotero que conduce al Cielo era sólo una cuestión de fe personal incomunicable racionalmente y por ello propiciaba la tolerancia en materia religiosa. No muy diferente era la opinión de Bartolomé de Las Casas cuando afirmaba que snadie está obligado a creer por encima de sus posibilidades". ${ }^{121} \mathrm{Si}$ algo distingue al fanático religioso, es decir, a quien profesa públicamente la intolerancia, es la invocación de sus propias creencias como pauta de comportamiento social válida también para quienes no comparten su fe.

Las buenas razones son las que parten de una actitud de imparcialidad, es decir, de la consideración de los intereses de los demás en tanto seres autónomos, capaces de formular planes de vida respetables en la medida en que no violen el principio de daño sostenido por John Stuart Mill o no sean expresión de una incompetencia básica que dé lugar a formas de paternalismo éticamente justificable.

La exigencia de imparcialidad, el ser capaces de ponernos en la situación del otro, es también una invitación a la indulgencia y a la aceptación de actos que no calzan exactamente con alguno de nuestros propios sistemas normativos.

No es muy aventurado afirmar que si la vida social estuviera guiada más por razones de imparcialidad que por las malas razones de las meras creencias que conducen a la intolerancia, la historia del mundo no incluiría la enorme dosis de tragedia individual y colectiva que la caracteriza. Ya Séneca lo sabía: «sólo una cosa nos puede dar la paz: el contrato de la indulgencia mutua». 122

La democracia parlamentaria es el mejor método hasta ahora existente para asegurar la indulgencia mutua en sociedades numerosas. El mercado, cuando respeta las exigencias de la justicia distributiva, es también la vía más adecuada para la realización de nuestras preferencias personales por lo que respecta a la adquisición de bienes privados. Por ello, es necesario someter ambas instituciones a la inspección permanente desde el punto de vista ético. Esto es lo que quería proponer en estas cuatro conferencias.

$$
* * *
$$

Llego así al final de este ciclo que lleva el nombre de un insigne filosofo de la moral en la España democrática, a quien también le ha preocupado el problema de lo que él llamaba "parlamentarismo a ultranza» ${ }^{223}$ y al que aquí me he referido señalando las "tendencias suicidas" de la democracia parlamentaria. 
Creo que es innecesario insistir en el honor que ha significado para mí participar en estas segundas conferencias Aranguren. Pero no lo es subrayar que mi propósito no ha sido exponer soluciones con pretensiones de validez absoluta, sino más bien contribuir al diálogo y a la discusión racionales sobre temas que preocupan o deben preocupar a todo demócrata liberal. La discusión franca y honesta es una de las manifestaciones más nobles del espíritu crítico. Y toda democracia se alimenta y adquiere vitalidad justamente de la práctica de la crítica. He procurado evitar el peligro de la retórica, al que ya los griegos temían porque sabían que la sugestión de las palabras podía fácilmente ser causa de extravío y de peligrosa manipulaciôn. Esto puede haber conferido a mi exposición una cierta aridez. Espero no haber violado los límites de lo tolerable.

A lo largo de muchos años -cuatro décadas- he procurado mantener contacto intelectual y humano con los pensadores democráticos y liberales españoles. A muchos de ellos les debo buena parte de mi formación intelectual y no poco apoyo fraternal y generoso en épocas en las que en mi país se vivió la soberbia cruenta de la dictadura, Es esta una oportunidad propicia para reiterar mi agradecimiento por tantas cosas buenas recibidas.

\section{NOTAS}

1. Cfr. Chandran Kukathas, "Are there any cultural rights?", Political Theory, vol. 20, n, 1 (febrero 1992), pp. 105-139, aquí p. 106.

2. Citado por Chandran Kukathas, op. cit., p. 107.

3. Para decirlo con palabras de Alasdair MacIntyre (After Virtue, Notre Dame, IN, University of Notre Dame Press, 1981, pp. $205 \mathrm{ss}$.): «Sin embargo, la particularidad [de las formas comunitarias, E.G.V.] no puede nunca ser dejada aträs o aniquilada. La idea de escapar de ella a un reino de máximas enteramente universales que pertenecen a la persona en tanto tal, sea en la forma kantiana del siglo de la llustración o en la presentación de algunos modemos filósofos morales actuales, es una ilusión y una ilusión con lamentables consccuencias».

4. Cfr. Charles Taylor, Hegel and Modem Society, Cambridge, MA, Harvand University Press, 1979, y del mismo autor, Soutces of the Self. The Making of Modem Identity, Cambridge, MA, Harvard University Press, 1989.

5. Cfr. Charles Taylor, Ilegel and Modem Society, op. cit, pp. 157-159.

6. Charles Taylor, Sources of Self, op. cit., pp. 27 ss.

7. Cfr. Michael I. Sandel, Liberalism and the Limits of Justice, Cambridge, Cambridge University Press, 1982, p. 150.

8. Cfr. Alasdair MacIntyre, After Virtue, op. cit., p. 201.

9. Ibidem, p. 205.

10. Ibidem.

11. Cfr. Immanuel Kant, "Grundlegung zur Metaphysik der Sitten", en Werke, t. IV, Darmstadt, Wissenschaftliche Buchgesellschaft, 1956, pp. 65 ss.

12. Michael Walzer, Spheres of Justice. A Defense of Pluralism and Equality, Nueva York, Basic Books, Inc. Publishers, 1983, p. 314.

13. La cuestion acerca de la comparabilidad ética de las culturas tiene una larga historia. Tzvetan Todorov la ha ilustrado brillantemente recordando las posiciones de Montaigne, Mon- 
tesquieu y Condorcet (cfr. T. Todorov, "El cruzamiento entre culturas", en Tzvetan Todorov y otros, Crice de culturas y mestizaje cultural, Madrid, Jücar Universidad, 1988, pp. 9-31). David Gauthier ofrece en Morals by Agreement, Oxford, Clarendon Press, 1986, pp. 288 ss., buenos criterios para juzgar acerca de la jerarquia ética de diferentes culturas.

14. Cfr, Will Kymlicka, Liberalism, Community and Culture, Oxford, 1989, pp. 165 ss.

15. Tidem, p. 165.

16. Ibidem, pp. $165 \mathrm{ss}$.

17. Cfr. Brian Barry, Theories of Justice, Berkeley / Los Ángeles, 1989, p. 301. Con respecto a la propuesta de respuesta que Gauthier ofrece a la pregunta del «tonto», cfr. Ruth Zimmerling, "La pregunta del tonto y la respuesta de Gauthier», Doxa, 6 (1989), pp. 49-76.

18. Cfr. Georg H. von Wright, The Varieties of Goodness, Londres, 1963, p. 215.

19. Cfr. Hans Kelsen, Das Problem des Parlamentarismus, Viena/Leipzig, 1925, p. 7.

20. Crr. José Luis Aranguren, "Democracia y representatividad", en La democracia establecida. Una critica intelectual, Madrid, Taurus, 1979, pp. 42-44, aqui p. 42.

21. Citado segin Hanna Pitkin, The Concept of Representation, Berkeley et al., University of California Press, 1967, p. 171.

22. Cfr. K.R. Popper, The Open Society and its Enemies, Londres, 1962, t. I, pp. 122 ss., y H. Steinberger, Konzeption und Grenzen freiheitlicher Demokratie, Berlin / Heidelberg / Nueva York, 1974, pp. $196 \mathrm{ss.}$

23. Cfr. K. Popper, op. cit., p. 123.

24. Cfr. John Austin. The Province of Jurisprudence Determined, Londres, 1954, p, 194.

25. Cfr. Thomas Comides, "Der Widerruf von Befehlen», Studium Generate, 22 (1969), pp. 1.215-1.263.

26. Cfr. Jean Bodin, Les six Livres de la Rëpublique, Aalen, 1961, p. 132.

27. Dicho sea de paso, el problema no cambia si en vez de atribuir la soberanía al parlamento se la hace radicar en el pueblo. Justamente en este caso pensaba Platón cuando criticaba la democracia.

28. Cfr. James M. Buchanan, The Limits of Liberty. Between Ararchy and Leviathan, Chicago/Londres, The University of Chicago Press, 1975.

29. Ibidem, p. 162.

30. Ibidem, p. 150.

31. Cfr. Paul Hirst, Representative Democracy and Its Limits, Cambridge, Polity Press, 1990, p. 31.

32. Citado según Steven Lukes, Power: A Radical View, Londres, Macmillan Education LTD, $1991^{15}$, pp. 18 ss.

33. Cfr. Peter Bachrach y Morton S. Baratz, Macht und Arnut. Eine theoretisch-empintsche Untersuchung, Francfort, Sulrkamp, 1977, p. 47.

34. Ibidem.

35. Cfr. Charles R. Beitz, political Equality, Princeton, Princeton University Press, 1989, po. $12 \mathrm{ss}$.

36. Cfr. Bachrach y Baratz, op. cit., p. 47.

37. Roberto Unger citado según Andrew Altman, Critical Legal Studies. A Liberal Critique, Princeton, Princeton University Press, 1990, p. 59.

38. Citado según A. Altman, op. cit., p. 61.

39. Cfr. Paul Hirst, op. cit. pp. 26 ss.

40. Cfr. James M. Buchanan, op. cit., p. 162.

41. Cfr. Amartya Sen, "The moral standing of the market", Social Philosophy \& Policy, 2, 2 (primav, 1985), pp. 1-19, aquí p. 9.

42. Cfr. James M. Buchanan, op. cit., p. 25.

43. Cfr. Robert Nozick, Anarchy, State, and Utopia, Oxford, Basil Blackwell 1974, pp. 153 ss.

44. Crr. Allan Gibbard, "What's morally special about frec exchange», Social Philosophy \& Policy 2, 2 (primav. 1985), pp, 20-28, aquí p. 22. 
45. Cfr. R. Coase, "The Problem of Social Cost", Joumal of Law and Economics, 3 (1960), pp. 1-44.

46. Ibidem, p. 2.

47. Ibidem, p. 44.

48. Cfr: Walter Eucken, Grundsälze der Wirtschaftspolitik, Tubinga, J.C.B. Mohr (Paul Siebeck), $1990^{6}$, p. 53.

49. Citado segúr Walter Eucken, op. cit., p. 357.

50. Cfr. Charles R. Beitz, Political Equality, Princeton, Princeton University Press, 1989. p. 20.

51. Cfr. Milton Friedman, Free to Choose, Londres, 1980, p. 223.

52. Cfr. Tibor R, Machan, "The Virtue of Freedom in Capitalism", Joumal of Applied Philosophy, vol. $3, \mathrm{n}^{\circ} 1$ (1986), pp. 49-58, p. 50.

53. Citado según Walter Eucken, op. cit, p. 351.

54. Cf. Tibor R. Machan, op. cit., p, 51.

55. Ibidem.

56. Cfr. Milton Friedman, Capitalism and Fredom, Chicago, 1962, p. 9.

57. Ibidem, pp. $15 \mathrm{ss.}$

58. Cfr. Amartya Sen, op. cit., p. 10.

59. Cfr. Brian Barry, «Lady Chatterley's Lover and Doctor Fischer's Bomb Party: Liberalism, Pareto Optimality, and the Problem of Objectionable Preferences», Liberty and Justice (Oxford), 2 (1991), pp. 78-109, p, 95.

60. James M. Buchanan, Liberty, Market and State, Oxford University Press, 1986, p. 136.

61. Cfr. Hans-Peter Müller, "Markt, Stant und individuelle Freiheit", en Lucian Kem y Hans-Peter Müller (comps), Gerechtigkeit. Diskurs oder Markt?, Opladen, 1986, pp. 127-148.

62. Cfr. Ken Hanly, "The Problem of Social Cost: Coase's economics versus ethicsn, Journal of Applied Philosophy, vol. 9, n. 1 (1992), pp. 77-83, p. 79.

63. Cfr, Allan Gibbard, op. cit., pp. 26 ss.

64. Cfr. Carlos S. Nino, Fundanentos de derecho constitucional, Buenos Aires, 1992, p. 373.

65. Ibidem.

66. Cfr, James S. Fishkin, Democracy and Deliberation, Yale University Press, New Haven $/$ Londres, 1991, p. 69.

67. Cfr. Adam Smith, Wealth of Nations, Londres, Routledge, s.f., libro 4, cap. 8, p. 517.

68. Cfr. Walter Eucken, op. cit., p. 31.

69. Ibidem, pp. 42 ss.

70. Ibidem, p. 53.

71. Cfr, José Luis Aranguren, Ética y poittica, Madrid, Guadarrama, s.f, p. 225.

72. Cfr. Konrad Hesse, Grundzilge des Verfassungsrechts der Burndesrepublik Deulschtand, Karisruhe, 1975, p. 277.

73. Cfr. Robert Alexy, Theorie der Grundrechte, cap. 9.

74. Cfr. Emesto Garzón Valdés, "Acerca de las limitaciones juridicas del soberano», Sistema (Madrid), 43-44 (sept. 1981). pp. 43-56. p. 159.

75. Cfr. Niklas Luhmann, Legitimation durch Verfahren, Darmstadt/Neuwięd, 1975,

76. Ibidem, pp. $29 \mathrm{ss}$.

77. Cfr. Jürgen Habermas, Moralbewusstsein und kommunikatives Handein, Francfort, 1983, p. 72.

78. Cfi. James S. Fishkin, «Bargaining. Justice and Justification», Social Philosophy \& Poticy, vol. 5, $2(1988)$, p. 61 .

79. Ibidem, p. 62.

80. Cfr. Francisco de Vitoria, Relectio de Indis, Madrid, 1967, p. 94.

81. Cfr. James M. Buchanan, The Limits of Liberty. Between Anarchy and Leviathan, Chjcago/Londres, The University of Chicago Press, 1975, p. 24. 
82. Ibidert, pp. 59 ss.

83. Ibidem, p. 2.

84. Cfr. David Gatuthier, Morals by Agreement, Oxford, 1986, p. 192.

85. Cfr. James Fishkin, op. cit., p. 54.

86. Crr. David Gauthier, Morals by Agreement, op. cit., p. 33.

87. A menos que tuvieran ciertas dudas acerca de la firmeza de sus convicciones, como el célebre Dr. Sebastian Röttinger (1537-1608), abogado del Consejo Municipal de Nördlingen quien, por una parte, con sus informes «juridicos» colaboró eficazmente en la quema de brujas (35, según las crónicas municipales) y, por otra, en su testamento lego 3.000 onzas de oro para becas "a fin de reconciliarse con la posteridad". Lcase su lápida en la iglesia de St. Georg en Nördlingen, Baviera.

88. CFr. James Fishkin, op. cit., p. 58.

89. Cfr. Javier Muguerza, «La alternativa del disenso. (En torno a la fundamentación ética de los derechos humanos)n, en Javier Muguerza y otros autores, El fundamento de los derechos humanos (ed. preparada por Gregorio Peces-Barba Martínez), Madrid, Debate, 1989, pp. 19-56, aquí p. 45.

90. Crr, Dolf Stemberger, Herrschaft und Vereinbarting, Francfort, Sulukamp, 1986, pp. 129 ss.

91. Cfr. Javier Muguerza, op. cit., p. 45.

92. Ibidem, p. 54.

93. Cfr. Brian Barry, Theories of Justice, vol. 1, Berkeley $/$ Los Ángeles, University of California Press, 1989, p. 361.

94. Cfr. Javier Muguerza, op, cit., p. 51.

95. Cfr. Michael Davis, «Nozick's Argument for the Legitimacy of the Welfare State", Ethics, 97 (abril 1987), pp. 576-594, aqui p. 592. El razonamiento aqui expuesto sigue la línea argumentativa de Davis.

96. Ibidem, p. 594 ,

97. Con respecto a esta línea argumentativa, cfr. Hans-Peter Müller, op. cit.

98. Andrew Altman, Critical Legal Studies. A Liberal Critique, Princeton, Nueva Jersey, 1990, pp. 57 ss.

99. Ibidem, p, 66 .

100. Bbidem, p. 14.

101. Cfr. E. Garzón Valdés, "No pongas tus sucias manos sobre Mozart. Algunas consideraciones sobre el concepto de tolerancian, Claves (Madrid), $n .{ }^{\circ} 19$ (enero-febrero 1992), pp. 16-23.

102. Cfr. Herbert Marcuse, "Repressive Toleranz", en Robert Paul Wolff, Barington Moore y Herbert Marcuse, Kritik der reinen Toleranz, Francfort, Suhrkamp, 1966, pp. 91-128, aqui p. 94.

103. Ibidem, pp. $101 \mathrm{ss.}$

104. Cfr. Kenneth J. Arrow, "Values and Collective Decision-Making», en Peter Laslett y W.G. Runciman (eds.), Philosophy, Politics and Society, Blackwell, Oxford, 1967, pp. 215-232, aquí p. 226, Third Series.

105. Cfr. Juan Ginés de Sepúlveda, Tratado sobre las justas causas de la guerra contra los indios, México, Fondo de Cultura Económica, 1941, p. 101.

106. Cfr. H.L.A. Hart, The Concept of Law, Oxford, 1961, pp. 190 ss.

107. Cfr. David Hume, An Inquiry conceming the Principles of Morals, Indianápolis / Nueva York, 1957, p. 93.

108. Cfr. Hermann Heller, "Politische Demokratie und soziale Homogenität», en Gesammelte Schriften, t. 2. Leiden, A.W. Sijthoff, 1971, pp. 421-433, aquí p. 430.

109. Cfr. José Luis Aranguren, Etica y política, op. cit., p. 205.

110. Cfr. Hans Kelsen, Das Problem des Parlamentarismus, Viena/Leipzig, 1925, p. 31.

111. Citado según Jorge R. Vanossi, "Enfoque juridico de la compción en las Américas», Propuesta y Control (Buenos Aires), 23 (1992), pp. 2.558-2.572, 2.569. 
112. Konrad Hesse, Grundzige des Verfassungsrechts der Bundesrepublik Detutschland, Karlsruhe, $1975^{\circ}$, pp. 62 ss.

113. Ibidem, p. 161.

114. Crr. I. Kant, La paz perpetua (trad, de Joaquín Abellán), Madrid, Tecnos, 1985, pp. $61 \mathrm{ss}$.

115. Cfr. John Rawls, A Theory of Justice, Oxford, Clarendon Press, 1972, p. 582. Agradezco esta referencia a Ruth Zimmerling como así también sus inteligentes críticas a la primera versión de este trabajo.

116. Cfr. Robert Alexy, Theorie der Grundrechte, Francfort, 1986, pp. 75 ss.

117. Cfr. Brian Barry, op. cit, p. 87.

118. A. Sen, op. cit., p. 13.

119. Cfr. Alan Haworth, "Capitalism, Freedom and Rhetoric: a reply to Tibor R. Machan, Joumal of Applied Philosophy, vol. 6, n. ${ }^{2} 1$ (1989), pp. 97-106, n. 6 .

120. Cfr. Thomas Nagel, aMoral Conflict and Political Legitimacy», Philosophy \& Public Affairs, vol. 16, n." 3 (verano 1987), pp. 215-240, aquí p. 221.

121. Cfr. Bartolomé de Las Casas, Derechos civites y politicos, Madrid, 1974, p. 155. p. 320 .

122. Cfr. Séneca, Moral Essays, 3 t., Cambridge, MA, Harvard University Press, 1958, t. 1 ,

123. Cf. José Luis Mrangurcn, La democmcia establecida. Una critica intelectual, Madrid, Taurus, 1979, p. 68 . 